\title{
Article \\ Murine Oncostatin M Has Opposing Effects on the Proliferation of OP9 Bone Marrow Stromal Cells and NIH/3T3 Fibroblasts Signaling through the OSMR
}

\author{
Lena Jakob ${ }^{1}$, Tony Andreas Müller ${ }^{1,2}$ (D), Michael Rassner ${ }^{1}$, Helen Kleinfelder ${ }^{1}$, Pia Veratti ${ }^{1}$, Jan Mitschke ${ }^{1}$, \\ Cornelius Miething 1,3 ${ }^{1}$, Robert A. J. Oostendorp ${ }^{4}\left(\mathbb{D}\right.$, Dietmar Pfeifer ${ }^{1}$, Miguel Waterhouse ${ }^{1}$ \\ and Justus Duyster $1,3, *$
}

check for updates

Citation: Jakob, L.; Müller, T.A.; Rassner, M.; Kleinfelder, H.; Veratti, P.; Mitschke, J.; Miething, C.; Oostendorp, R.A.J.; Pfeifer, D.; Waterhouse, M.; et al. Murine Oncostatin M Has Opposing Effects on the Proliferation of OP9 Bone Marrow Stromal Cells and NIH/3T3 Fibroblasts Signaling through the OSMR. Int. J. Mol. Sci. 2021, 22, 11649. https://doi.org/10.3390/ ijms222111649

Academic Editor: Orsola Di Martino

Received: 16 September 2021

Accepted: 25 October 2021

Published: 28 October 2021

Publisher's Note: MDPI stays neutral with regard to jurisdictional claims in published maps and institutional affiliations.

Copyright: () 2021 by the authors Licensee MDPI, Basel, Switzerland. This article is an open access article distributed under the terms and conditions of the Creative Commons Attribution (CC BY) license (https:/ / creativecommons.org/licenses/by/ $4.0 /)$.
1 Department of Hematology and Oncology, Freiburg University Medical Center, Albert-Ludwigs-University of Freiburg, Hugstetter Str. 55, 79106 Freiburg, Germany; lena.jakob@uniklinik-freiburg.de (L.J.); tony.mueller@uk-koeln.de (T.A.M.); Michael.rassner@uniklinik-freiburg.de (M.R.); helen.kleinfelder@uniklinik-freiburg.de (H.K.); pia.veratti@uniklinik-freiburg.de (P.V.); Jan.mitschke@uniklinik-freiburg.de (J.M.); Cornelius.miething@uniklinik-freiburg.de (C.M.); dietmar.pfeifer@uniklinik-freiburg.de (D.P.); miguel.waterhouse@uniklinik-freiburg.de (M.W.)

2 Center for Integrated Oncology (CIO), Department I of Internal Medicine, Aachen-Bonn-Cologne-Duesseldorf, Excellence Cluster for Cellular Stress Response and Aging-Associated Diseases (CECAD), Center for Molecular Medicine Cologne (CMMC), University of Cologne (UoC), 50937 Cologne, Germany

3 German Cancer Consortium (DKTK) and German Cancer Research Center (DKFZ), 69120 Heidelberg, Germany

4 Department of Internal Medicine III, Technical University of Munich, Klinikum Rechts der Isar, 81675 Munich, Germany; robert.oostendorp@tum.de

* Correspondence: justus.duyster@uniklinik-freiburg.de; Tel.: +49-761-2703-4060

\begin{abstract}
The IL-6 family cytokine Oncostatin M (OSM) is involved in cell development, growth, hematopoiesis, inflammation, and cancer. Intriguingly, OSM has proliferative and antiproliferative effects depending on the target cell. The molecular mechanisms underlying these opposing effects are not fully understood. Previously, we found OSM upregulation in different myeloproliferative syndromes. However, OSM receptor (OSMR) expression was detected on stromal cells but not the malignant cells themselves. In the present study, we, therefore, investigated the effect of murine OSM (mOSM) on proliferation in stromal and fibroblast cell lines. We found that mOSM impairs the proliferation of bone marrow (BM) stromal cells, whereas fibroblasts responded to mOSM with increased proliferation. When we set out to reveal the mechanisms underlying these opposing effects, we detected increased expression of the OSM receptors OSMR and LIFR in stromal cells. Interestingly, Osmr knockdown and Lifr overexpression attenuated the OSM-mediated effect on proliferation in both cell lines indicating that mOSM affected the proliferation signaling mainly through the OSMR. Furthermore, mOSM induced activation of the JAK-STAT, PI3K-AKT, and MAPK-ERK pathways in OP9 and NIH/3T3 cells with differences in total protein levels between the two cell lines. Our findings offer new insights into the regulation of proliferation by MOSM.
\end{abstract}

Keywords: mOSM; proliferation; JAK-STAT; OSMR; LIFR

\section{Introduction}

The IL-6 family cytokine Oncostatin M (OSM) was first described as a factor released by U937 lymphoma cells with the ability to inhibit the growth of the human melanoma cells A375 in vitro [1]. Numerous studies have since revealed its role in different physiological and pathological processes such as cell growth [1], development [2,3], inflammation [4], hematopoiesis [2,5,6], and cancers [7-13].

Physiologically, OSM is released by activated leukocytes including macrophages $[1,14]$, monocytes [15], T-lymphocytes [16,17], dendritic cells [18] and neutrophils [19-23]. Similar 
to other IL-6 family cytokines, OSM affects target cells by binding to membrane receptors consisting of two subunits: the transmembrane protein gp130 and a ligand-specific subunit [24,25]. Human OSM (huOSM) activates a type I OSM receptor, composed of gp130 and leukemia inhibitory factor receptor (LIFR), or a type II OSM receptor composed of gp130 and OSMR [26,27], whereas murine OSM (mOSM) mainly interacts with the type II OSM receptor $[28,29]$. However, there is also evidence for $\mathrm{mOSM}$ signaling involving both type I and II OSM receptors in bone formation and resorption [30,31]. LIFR is expressed by various cell types including hematopoietic cells, while the expression of OSMR is restricted to mesenchymal cells like fibroblasts, endothelial cells, osteoblasts, and epithelial cells, and a number of cancer cells [32].

Generally, the cellular responses and downstream pathway activation after OSM binding to its receptors are highly dependent on the target cell type. Activation of type I and II receptors by OSM induces downstream pathways such as JAK-STAT, MAPKERK, and PI3K-AKT [33-35]. More recent studies revealed activation of c-Jun N-terminal kinase (JNK), p38 mitogen-activated protein kinase [36] and protein kinase C-delta (PKCd) pathways by OSM [37-39].

Although OSM was initially described as an antiproliferative cytokine inhibiting the growth of melanoma, breast cancer, chondrosarcoma, lung adenocarcinoma, and glioblastoma cells [1,40-43], it has also been shown to promote proliferation in various cell lines [44-49]. The mechanisms of these differential effects on certain cell types are not fully understood yet.

In previous studies, OSM was found to be upregulated in different myeloproliferative syndromes [50,51]. Its receptor OSMR however is not expressed on the malignant cells themselves but can be found on bone marrow stromal cells [6,52]. This indicates that stromal cells as part of the tumor microenvironment might be involved in tumor progression. It is known that aberrant proliferation and interaction of tumor cells with their microenvironment are important part aspects of tumorigenesis [53,54].

In the present study, we, therefore, investigated the molecular mechanisms leading to the opposing effects of OSM on proliferation in murine bone marrow stromal cells and fibroblasts.

\section{Results}

\subsection{OSM Has Differential Effects on the Proliferation of BM Stromal Cells and Fibroblasts}

Based on its upregulation in various cancer entities [7-13] and its controversial role in tumorigenesis, we investigated the differential effects of OSM on the proliferation of stromal cells and fibroblasts. In an initial experiment, we treated the murine BM stromal cell lines OP9, and M2-10B4, the murine fetal liver stroma cell line EL08-1D2 as well as primary BM stromal cells with OSM and analyzed the cell cycle progression and proliferation using an EdU incorporation assay. The proliferation of OP9 (Figure 1B), EL08-1D2 (Figure S1A) and M2-10B4 (Figure S1B) was impaired by $\mathrm{mOSM}$, indicated by a reduced percentage of cells undergoing the S phase, while the percentage of cells remaining in the G0/G1 phase was increased. The inhibitory effect of mOSM was most pronounced for OP9 cells demonstrating OSM-induced reduction of $S$ phase percentage by $52 \%$, compared to $S$ phase percentage reduction of 19\% in EL08-1D2 and 30\% in M2-10B4 cells. Consistent with the effect of OSM on the BM stromal cell lines, OSM treatment reduced the S phase percentage of murine primary stromal cells by $68 \%$ (Figure $1 \mathrm{~A}$ ) and human primary stromal cells by $28 \%$ (Figure S1C).

It has previously been demonstrated that mOSM promotes the proliferation of $\mathrm{NIH} / 3 \mathrm{~T} 3$ fibroblasts [55]. We confirmed that OSM-exposed NIH/3T3 cells presented with a 2.8-fold increase of $\mathrm{S}$ phase percentage compared to untreated cells. In contrast to OP9 cells, $\mathrm{NIH} / 3 \mathrm{~T} 3$ cells showed a reduction of cells remaining in the G0/G1 phase after mOSM treatment (Figure 1C). OP9 and NIH/3T3 cells are known to proliferate fast. To detect and compare the effects of mOSM on proliferation cell lines were starved for all experiments. 
control

\section{A MSC}

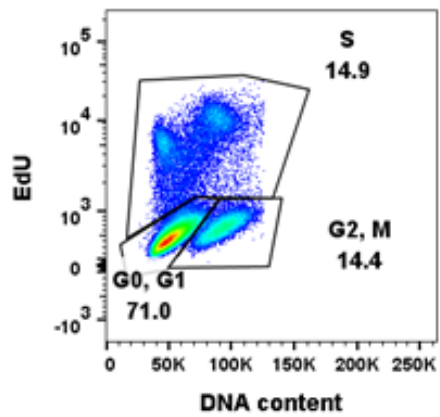

B OP9

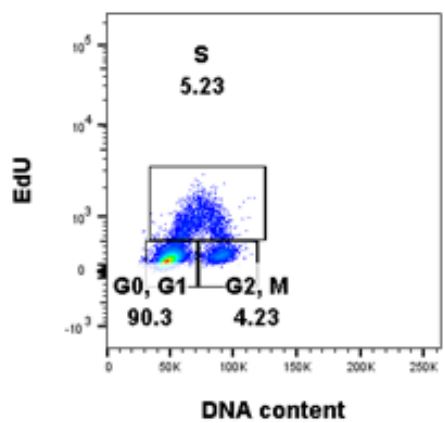

C NIH/3T3

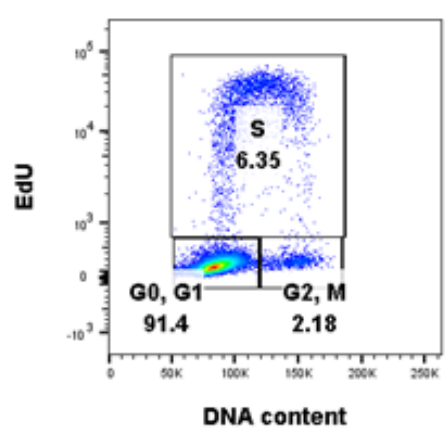

OSM
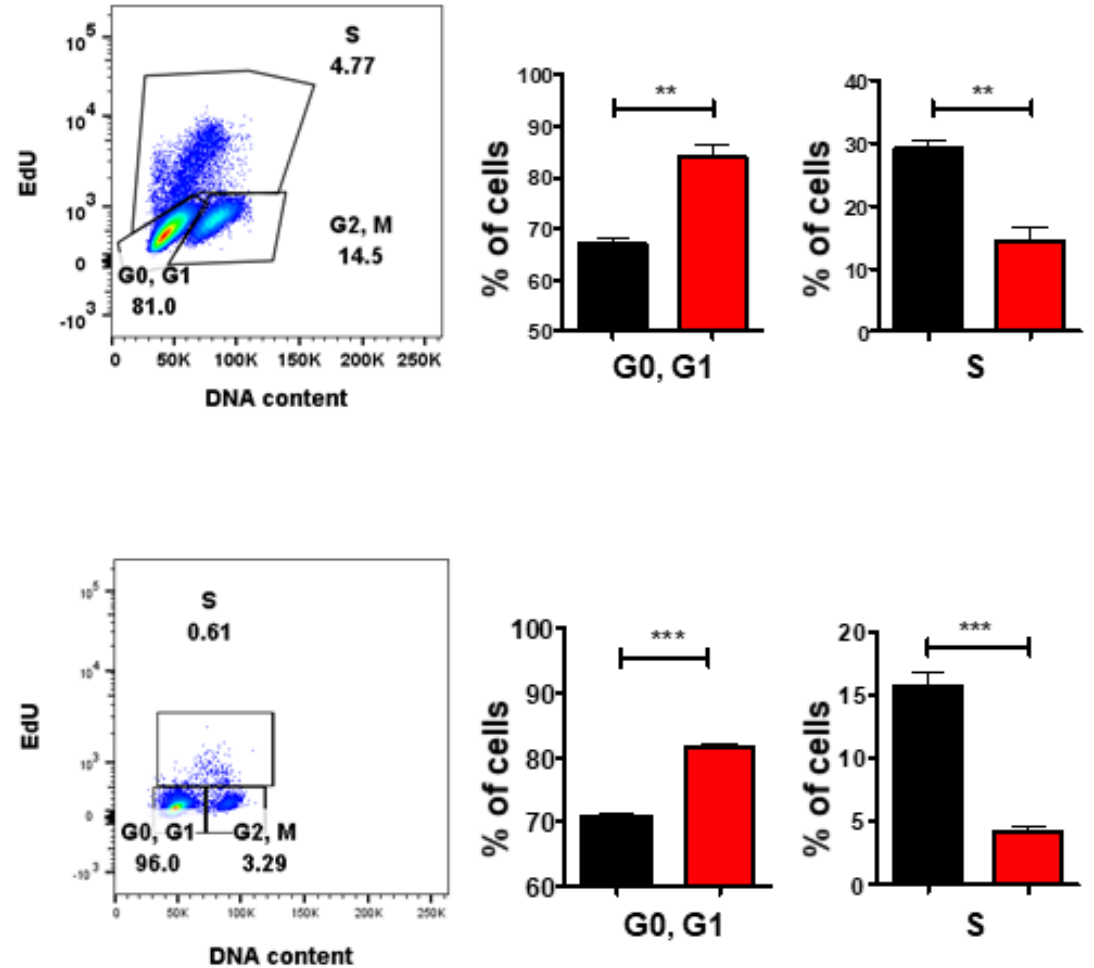

control

OSM

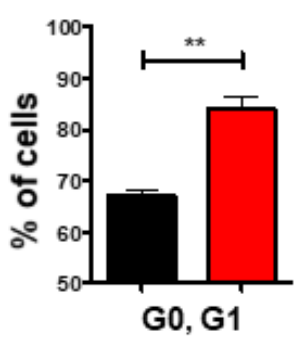

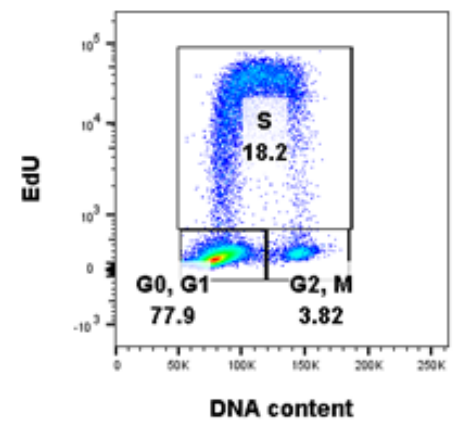
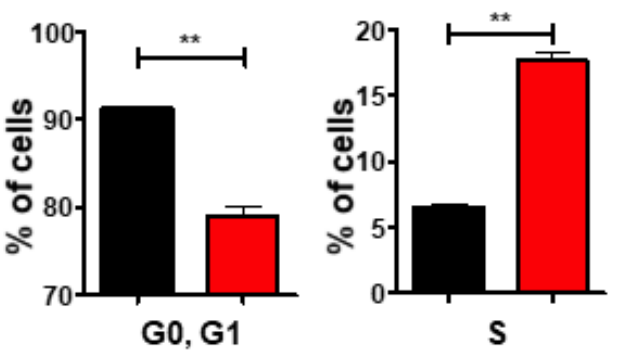

Figure 1. OSM has differential effects on the proliferation of BM stromal cells and fibroblasts. Representative FACS plot (left) and quantification of cell cycle phases (right) of (A) primary murine BM stromal cells and (B) OP9 cells and (C) NIH/3T3 cells in presence or absence of $10 \mathrm{ng} / \mathrm{mL}$ mOSM. For A, cells were cultured in a medium containing $10 \%$ FCS and treated with mOSM for $24 \mathrm{~h}$. For B and C, cells were serum-starved for $6 \mathrm{~h}$ and treated with mOSM for $24 \mathrm{~h}$. The proliferation was assessed using EdU incorporation. Cells were exposed with EdU during the last hour of treatment (B,C) or the last $12 \mathrm{~h}$ of treatment (A). The DNA content was quantified using FxCycle ${ }^{\mathrm{TM}}$ Violet Stain. Student's unpaired $t$-test. ${ }^{* *} p<0.01$, and $* * * p<0.001$.

\subsection{OP9 and NIH/3T3 Cells Show Differential Levels of OSMR and LIFR}

To understand the mechanism leading to the differential effects on proliferation, we investigated the receptors activated by mOSM. Murine OSM is known to signal mainly via the OSMR [28], and to a lesser extent via the LIFR [30,31]. Interestingly, immunoblot analysis revealed higher overall protein levels of OSMR and especially LIFR in OP9 cells compared to NIH/3T3 cells (Figure 2A). It has been demonstrated before, that B cells do not 
express OSMR and LIFR [32], therefore the pro-B cell line $\mathrm{Ba}$ /F3 served as a negative control. Consistent with the immunoblot data, we detected increased Lifr mRNA expression in OP9 cells compared to NIH/3T3 cells in microarray analyses, whereas Osmr mRNA expression was not altered between both cell lines (Figure 2B). Additionally, flow cytometric analysis revealed strong LIFR surface expression on OP9 cells, whereas LIFR was hardly detectable on NIH/3T3 cells (Figure 2C). These findings suggest the role of the OSM-LIFR signaling axis on the proliferation of $\mathrm{OP} 9$ cells.

Proper determination of murine OSMR (mOSMR) surface expression was not possible despite using different flow cytometry antibodies supposed to bind mOSMR (R\&D Systems FAB662P, Santa Cruz sc-21797 PE).

We next investigated whether mOSM treatment affects the expression of the OSMR and LIFR in OP9 and NIH/3T3 cells. We detected an initial reduction of total cellular OSMR in both cell lines one hour after mOSM treatment, followed by a return to basal levels after $8 \mathrm{~h}$ of mOSM exposure. For the LIFR, a similar regulation pattern expression in OP9 cells was observed with initial downregulation followed by upregulation. In contrast, NIH/3T3 cells retained low-level expression of the LIFR during mOSM treatment (Figure 2D). These results were confirmed by time-course analysis of LIFR surface expression, which was significantly reduced upon mOSM treatment in OP9. Conversely, the mOSM-induced reduction was only slightly detectable in NIH/3T3 cells, possibly due to little LIFR surface expression (Figure 2E). Based on these findings, we conclude that mOSM signals via both OSMR and the LIFR in OP9 cells, whereas NIH/3T3 cells show only marginal LIFR expression and mOSM signaling in this cell line might be largely limited to OSMR. Western Blot quantification is attached in Figure S2.

\subsection{OSMR Downregulation Attenuates OSM Effects on Proliferation}

To investigate the synergistic or antagonistic roles of OSMR or LIFR and MOSM on proliferation, we established an shRNA-mediated knockdown of Osmr or Lifr in both OP9 and NIH/3T3 cell lines. Knockdown efficacy of four Osmr-specific shRNAs and five shRNAs targeting the Lifr were evaluated (Figure 3A,B). Exposure times of immunoblots were different between OP9 and NIH/3T3 cells due to lower OSMR and LIFR expression in NIH/3T3 cells. In OP9 cells, targeting Osmr, but not Lifr partly abolished the mOSMinduced antiproliferative effect compared to cells transfected with an unrelated control shRNA. In contrast, both Osmr and Lifr knockdown reduced the mOSM-mediated proliferative effect in NIH/3T3 cells (Figure 3C). Our results indicate that the mOSM effects on proliferation are mainly mediated by the OSMR, with only little impact by the LIFR.

In a further step, we analyzed the effect of stable Lifr overexpression in both cell lines (Figure 3D). Flow cytometric analysis confirmed enhanced LIFR expression on the surface of Lifr-transduced cells (Figure 3E). Lifr overexpression attenuated the mOSM-mediated effect on proliferation by approximately $30 \%$ and $50 \%$ in Lifr-overexpressing OP9 and $\mathrm{NIH} / 3 \mathrm{~T} 3$ cells, respectively (Figure 3F). These results confirm our notion that OSMR is the main mediator of the mOSM effect on proliferation. Taken together, we demonstrate that the proliferative and antiproliferative ability of mOSM depends on signaling through the OSMR. Although mOSM does bind the LIFR, this interaction may only slightly affect cellular proliferation. 
A

OP9 NIH/3T3 BaF3

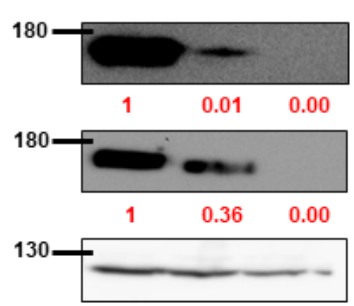

C

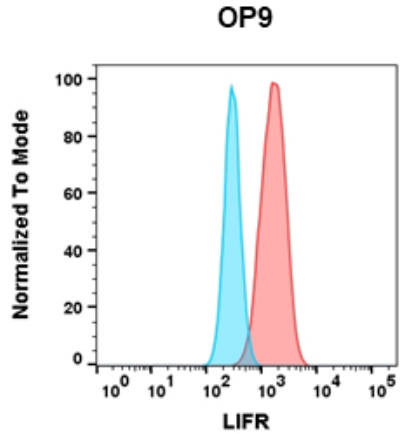

B
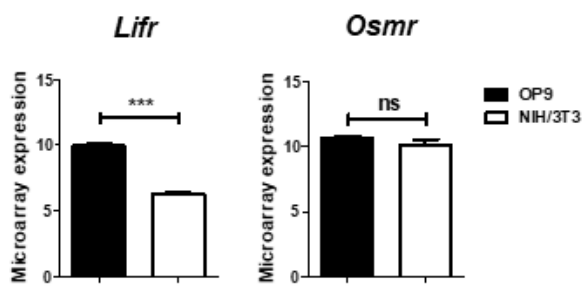

D
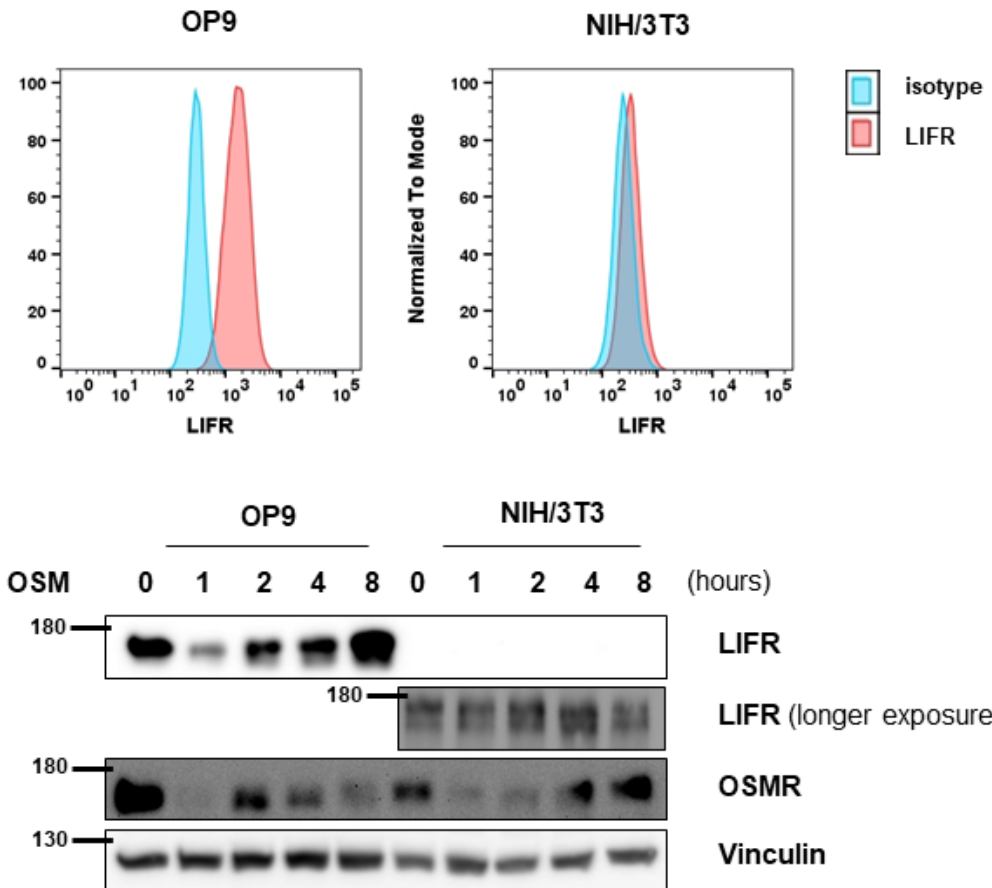

(hours)

LIFR

LIFR (longer exposure time)

OSMR

Vinculin

E

OP9

$\mathrm{NIH/3T3}$

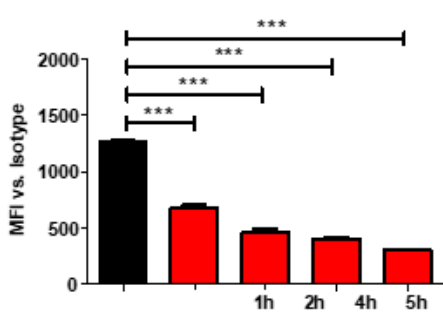

LIFR surface expression

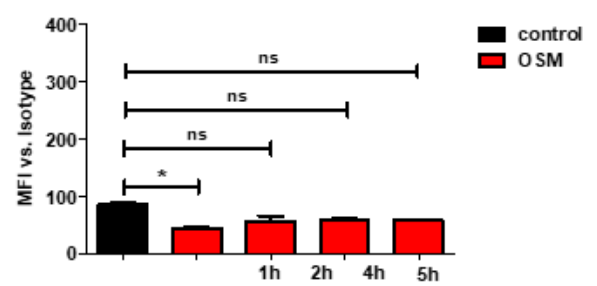

LIFR surface expression

Figure 2. OP9 and NIH/3T3 cells show differential levels of OSMR and LIFR. (A) OP9 and NIH/3T3 cells were examined for LIFR and OSMR expression. BaF3 cells were used as a negative control. Protein molecular weight is labeled in kDa. Relative protein quantities are marked in red. (B) Microarray analysis of OP9 and NIH/3T3 cells showing Osmr and Lifr expression. The $p$-values were calculated by Transcriptome Analysis Console software. ${ }^{* *} p<0.001$. ns = not significant. (C) OP9 and NIH/3T3 cells were analyzed for LIFR surface expression using FACS. (D) OP9 and NIH/3T3 cells were examined for expression of LIFR and OSMR in relation to different incubation periods with $10 \mathrm{ng} / \mathrm{mL}$ mOSM. Protein molecular weight is labeled in kDa. (E) OP9 and NIH/3T3 cells were examined for LIFR surface expression in relation to different incubation periods with $10 \mathrm{ng} / \mathrm{mL}$ mOSM. $p$-Values were calculated using one-way ANOVA and Bonferroni post-test. ${ }^{*} p<0.05$ and ${ }^{* * *} p<0.001$. ns $=$ not significant. 
A OP9

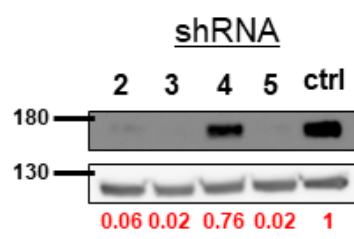

$\begin{array}{llllll}1 & 2 & 3 & 4 & 5 & \mathrm{ctrl}\end{array}$

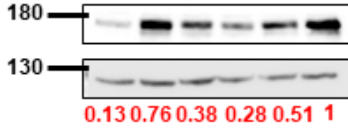

LIFR

Vinculin

(rel. quantification)
B $\quad \mathrm{NIH} / 3 \mathrm{~T} 3$

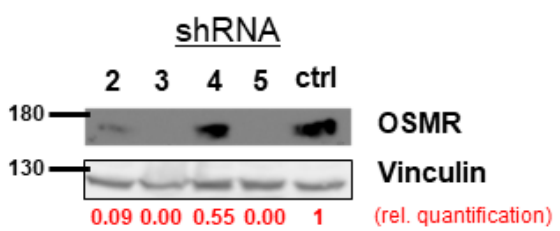

$\begin{array}{llllll}1 & 2 & 3 & 4 & 5 & \mathrm{ctrl}\end{array}$

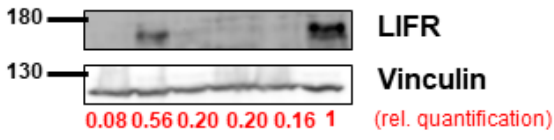

C OP9

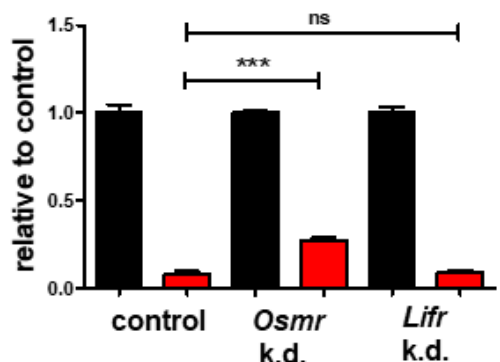

NIH/3T3

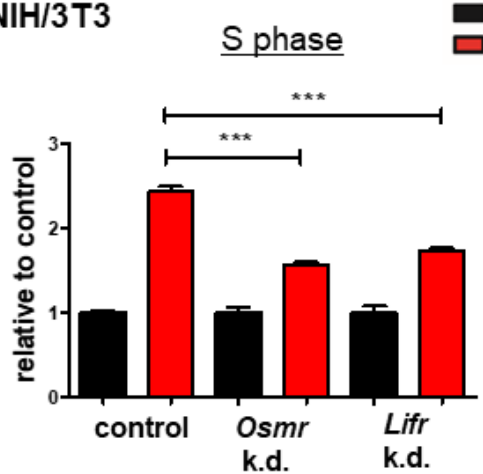

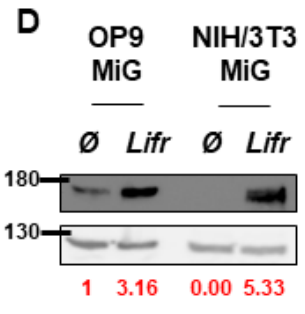

F

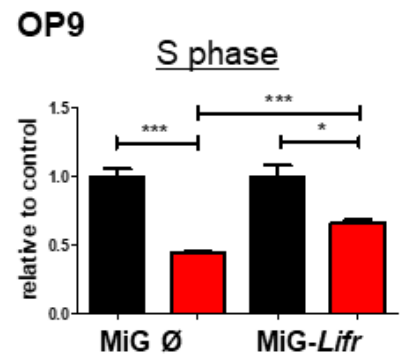

E

LIFR

Vinculin

(rel. quantification)

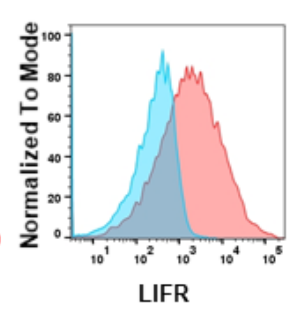

NIH/3T3

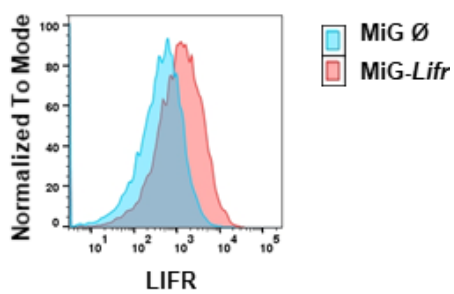

$\mathrm{NIH/3T3}$ control OSM 
A

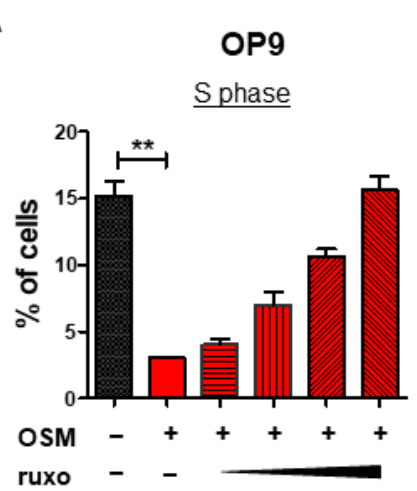

B

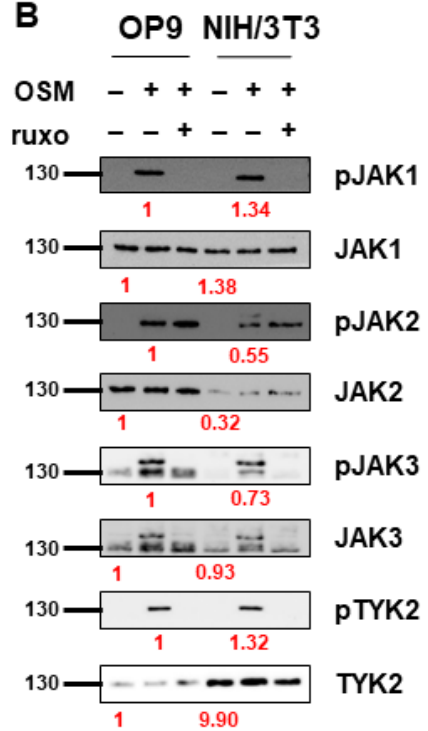

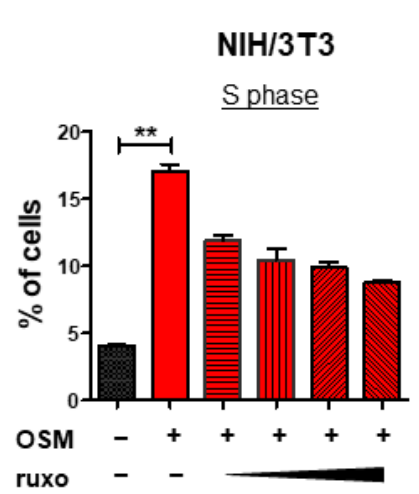

control

$\square$ OSM

OSM + ruxo $100 \mathrm{nM}$

血 OSM + ruxo $200 \mathrm{nM}$

D $O S M+$ ruxo $500 \mathrm{nM}$

OSM + ruxo $1 \mu \mathrm{M}$
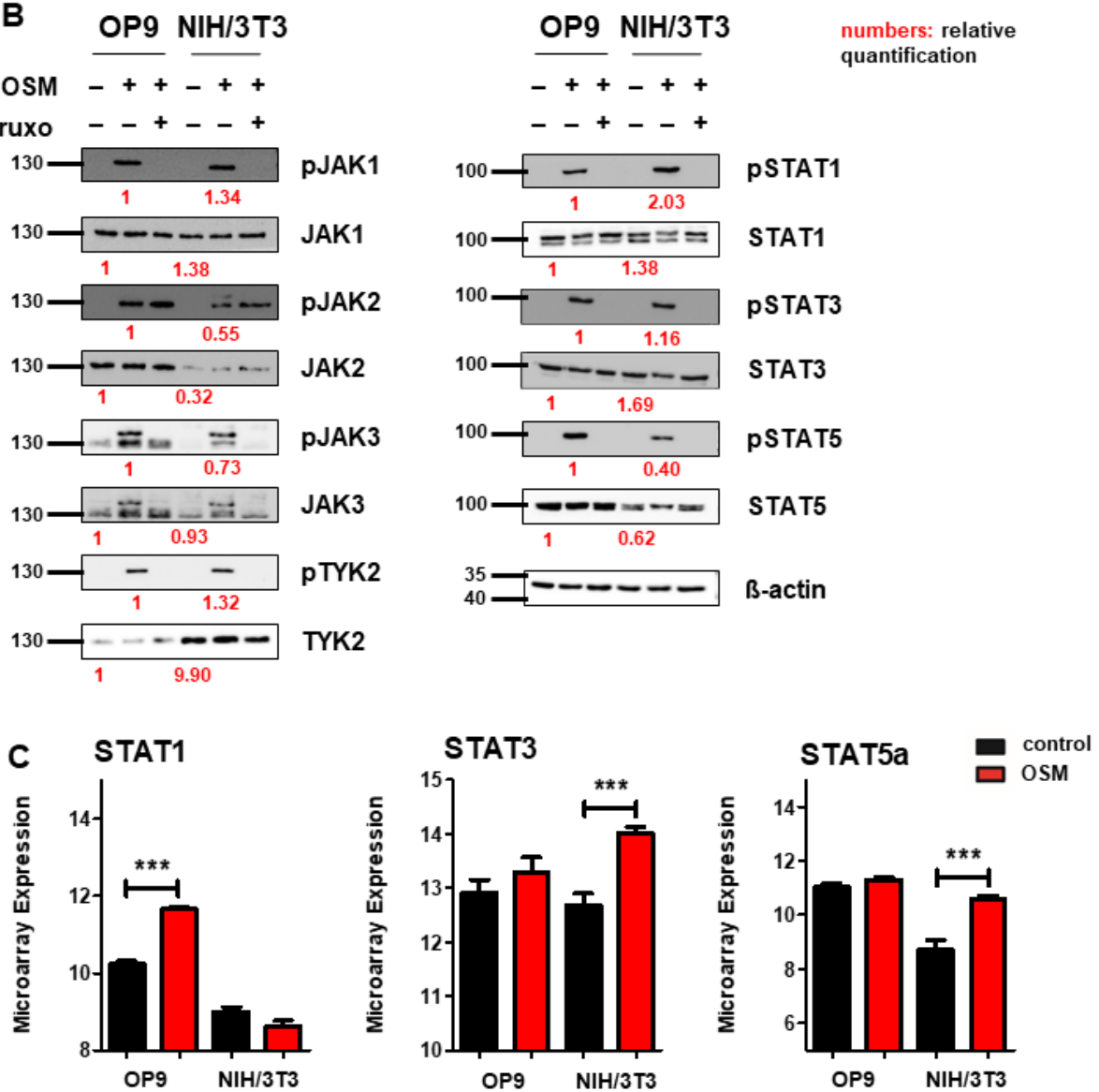

Figure 4. OSM activates the JAK-STAT pathway in OP9 and NIH/3T3 cells. (A) Quantification of $\mathrm{S}$ phase using an EdU incorporation assay. Cells were serum-starved for $6 \mathrm{~h}$ and treated for $24 \mathrm{~h}$ with $10 \mathrm{ng} / \mathrm{mL} \mathrm{mOSM} \mathrm{+/} \mathrm{-} \mathrm{ruxolitinib} \mathrm{(ruxo)} \mathrm{at} \mathrm{indicated} \mathrm{concentrations.} \mathrm{Student's} \mathrm{unpaired} t$-test. ** $p<0.01$. (B) OP9 and NIH/3T3 cells were used to examine the expression and activation of the JAK-STAT pathway at $10 \mathrm{ng} / \mathrm{mL} \mathrm{mOSM}+/-1 \mu \mathrm{M}$ ruxolitinib. Cells were serum-starved overnight. Ruxolitinib was added for $2 \mathrm{~h}$ and mOSM 15 min before harvesting the cells. Protein molecular weight is labeled in kDa. Relative protein quantities are indicated in red. (C) Microarray analysis of OP9 and NIH/3T3 cells showing STAT1, 3, and 5a expression. ${ }^{* * *} p<0.001$.

Immunoblot analysis of the JAK-STAT pathway revealed activation of all JAK family members JAK1, 2, 3, and TYK2 in response to MOSM in both OP9 and NIH/3T3 cells. STAT1, 3, and 5 were also activated in both cell lines. Pretreatment with ruxolitinib prevented the activation of all investigated STAT proteins (Figure 4B). Of note, JAK2 remained phosphorylated in presence of ruxolitinib, most probably in terms of ruxolitinib- 
induced hyperphosphorylation, which is not associated with JAK2 activity [57]. Total JAK2 and STAT5 levels were higher in OP9 cells, whereas TYK2 was stronger expressed in $\mathrm{NIH} / 3 \mathrm{~T} 3$ cells. The levels of JAK1, JAK3, STAT1, and STAT3 were not altered between OP9 and $\mathrm{NIH} / 3 \mathrm{~T} 3$ cells (Figure $4 \mathrm{~B}$ ). Interestingly, transcriptome analysis revealed upregulation of Stat 1 mRNA levels in OP9 and increased expression of Stat 3 and Stat 5 in NIH/3T3 cells in presence of mOSM for $6 \mathrm{~h}$ (Figure $4 \mathrm{C}$ ). These results indicate a similar signaling pathway activation in response to mOSM in OP9 and NIH/3T3 cells. However, differences in the expression and activation of JAK-STAT pathway members by mOSM between OP9 and $\mathrm{NIH} / 3 \mathrm{~T} 3$ cells might contribute to the differential effects on proliferation.

In addition, to activate the JAK-STAT pathway, OSM was shown to signal via the PI3K-AKT and MAPK-ERK pathways in various cell lines [47,58,59]. Correspondingly, we detected activation of AKT and ERK by mOSM in both OP9 and NIH/3T3 cells. Pretreatment with ruxolitinib prevented the activation of AKT and ERK (Figure 5A). Total ERK levels were elevated in NIH/3T3 compared to OP9 cells. Interestingly, mOSM reduced ERK expression in NIH/3T3, the addition of ruxolitinib reversed this effect. AKT levels were not altered between the cell lines (Figure 5A).
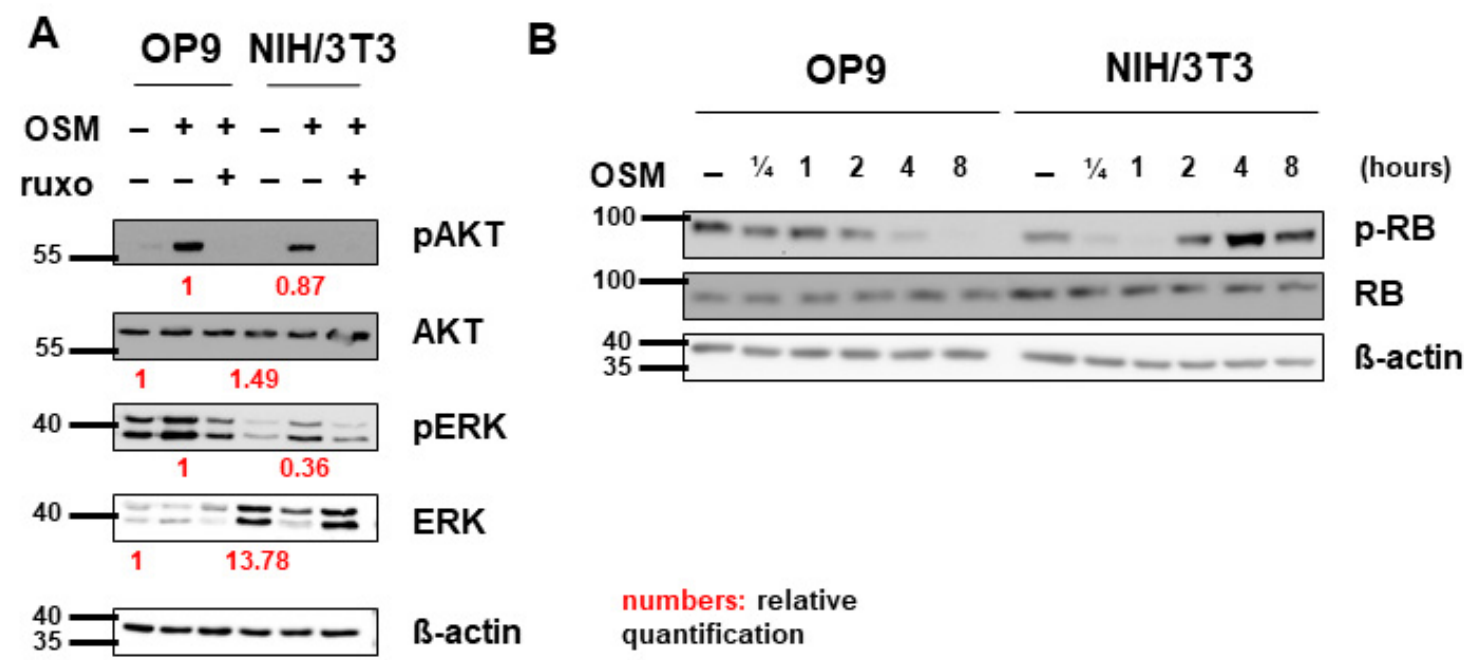

numbers: relative quantification

Figure 5. Pathway activation patterns were consistent with the OSM effect on proliferation. (A) OP9 and NIH/3T3 cells were used to examine the expression and activation of the MAPK-AKT and PI3K-ERK pathways at $10 \mathrm{ng} / \mathrm{mL} \mathrm{mOSM}+/-1 \mu \mathrm{M}$ ruxolitinib. Cells were serum-starved overnight. Ruxolitinib was added after $2 \mathrm{~h}$ and mOSM 15 min before harvesting the cells. Protein molecular weight is labeled in kDa. Relative protein quantities are indicated in red. (B) OP9 and NIH/3T3 cells were used to examine the expression and phosphorylation of retinoblastoma protein (RB) by mOSM for different time periods. Protein molecular weight is labeled in kDa.

\subsection{OSM Activates JAK-STAT, PI3K-AKT, and MAPK-ERK Pathways in OP9 and NIH/3T3 Cells}

After we found mOSM to exert its effects on proliferation through the OSMR in both cell lines, we were then interested in downstream signaling pathway activation and expression. Several studies have indicated that OSM/OSMR mediates its effects via activation of JAK-STAT signaling $[4,56]$. To study the role of this pathway on proliferation, $\mathrm{OP9}$, and NIH/3T3 cells were treated with MOSM in combination with the JAK1/JAK2specific inhibitor ruxolitinib at increasing concentrations from $100 \mathrm{nM}$ to $1 \mu \mathrm{M}$. In OP9 stromal cells, $1 \mu \mathrm{M}$ ruxolitinib fully restored the percentage of cells in the $S$ phase in $\mathrm{mOSM}$ treated cells to levels of untreated cells, while the proliferative effect of mOSM on NIH/3T3 cells was only partly reversed by ruxolitinib. Treatment with mOSM and $1 \mu \mathrm{M}$ ruxolitinib reduced the proliferative effect of mOSM in NIH/3T3 cells by $68 \%$ (Figure $4 \mathrm{~A}$ ). Ruxolitinib treatment alone did not affect the proliferation of these cell lines (Figure S3). These results 
suggest that activation of JAK1 and JAK2 is relevant for the mOSM-mediated effect on proliferation in both cell lines.

To investigate whether cell cycle regulating proteins are involved in the mOSMmediated proliferative effect, we examined the tumor suppressor proteins retinoblastoma protein (RB) and p53 in our cell lines. Interestingly, RB was phosphorylated in NIH/3T3 cells and dephosphorylated in OP9 cells upon mOSM treatment, consistent with the mOSM effect on proliferation. However, total RB levels were not altered between OP9 and $\mathrm{NIH} / 3 \mathrm{~T} 3$ cells before or after OSM treatment (Figure 5B) indicating that the differences in $\mathrm{RB}$ activation are a consequence of, but not the cause for the opposing effects of mOSM on proliferation. Western Blot quantification of $\mathrm{pRB}$ is attached in Figure S4. In the investigated cell lines, P53 levels were not affected by mOSM (data not shown).

To identify gene and protein classes up- or downregulated upon mOSM treatment we performed functional enrichment analysis of the global transcriptomes of OP9 and $\mathrm{NIH} / 3 \mathrm{~T} 3$ cells in the presence or absence of mOSM. OP9 cells showed gene set enrichment according to the antiproliferative effect of mOSM: "apoptotic signaling pathway" was positively enriched in response to mOSM, whereas "response to growth factors" and different developmental processes were negatively enriched (Figure S3A). In contrast, in NIH/3T3 cells, we detected positive enrichment of "pyrimidine metabolism" and negative enrichment of various differentiation processes upon mOSM treatment (Figure S3B). Moreover, functional enrichment analysis revealed that mOSM induces gene sets related to an inflammatory phenotype in both cell lines ("inflammatory response" and "response to interferon-beta"; Figure S3A,B). These results are in line with the well-known role of OSM to support inflammatory processes in various cell lines [4].

\subsection{IL-6 Has Synergistic Effects to OSM on the Proliferation of NIH/3T3 Cells}

We next analyzed mOSM-induced cytokine secretion in OP9 and NIH/3T3 cells, which might affect proliferation in an autocrine manner. For this purpose, supernatants of OP9 cells $(+/-$ mOSM treatment) were added to $\mathrm{NIH} / 3 \mathrm{~T} 3$ cells and vice versa for $24 \mathrm{~h}$, and cell cycle analysis was performed. OP9 cells treated with the supernatant of mOSM-stimulated $\mathrm{NIH} / 3 \mathrm{~T} 3$ cells showed impaired proliferative capacity indicated by lower S phase percentage. Conversely, NIH/3T3 cells treated with the supernatant of mOSM stimulated OP9 cells showed increased proliferation (Figure 6A), similar to direct treatment of these cells with mOSM (Figure 1C). We, therefore, assume that the differential effects of the supernatant on the proliferation of the two cell lines are not due to secondary effects of cytokines released in response to $\mathrm{mOSM}$, but rather a direct consequence of residual $\mathrm{mOSM}$ in the supernatant.

To analyze the cytokine release of $\mathrm{OP} 9$ and $\mathrm{NIH} / 3 \mathrm{~T} 3$ cells upon mOSM treatment, we performed a bead-based cytokine array of their supernatant. In accordance to other studies [60], we detected a strongly increased IL-6 production in mOSM treated OP9 cells compared to untreated cells $(254 \mathrm{pg} / \mathrm{mL}$ vs. $7.76 \mathrm{pg} / \mathrm{mL}, p<0.0001)$. NIH/3T3 cells also showed increased production of IL-6 upon mOSM treatment ( $13.9 \mathrm{pg} / \mathrm{mL}$ vs. not detectable), however significantly less than OP9 cells (Figure 6B). This was corroborated by transcriptome analysis revealing upregulation of IL-6 mRNA levels in OP9 and NIH/3T3 + mOSM (Figure S4A). In contrast, the release of the monocyte-attracting chemokine MCP-1/CCL2 was induced by mOSM in NIH/3T3, but not OP9 cells (Figure 6B). IL-10 and IL-27 levels were not significantly altered after mOSM treatment in both cell lines (Figure S4B). 
A OP9

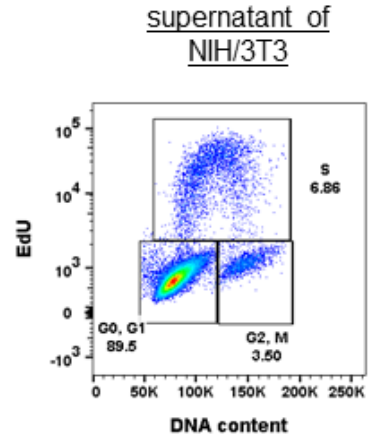

NIH/3T3

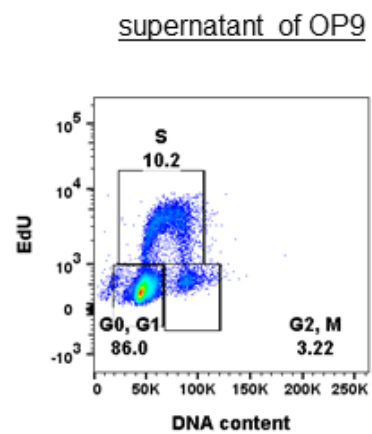

B

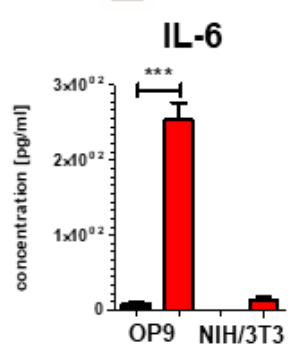

D
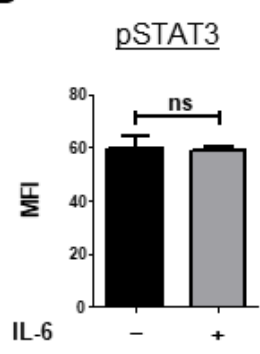

supernatant of $\mathrm{NIH/3T3}$ with OSM

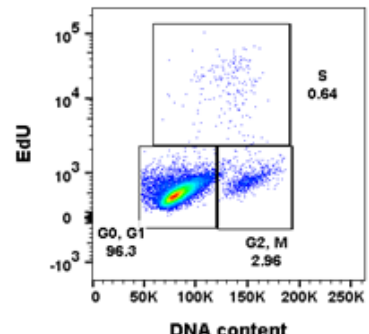

supernatant of OP9 with OSM

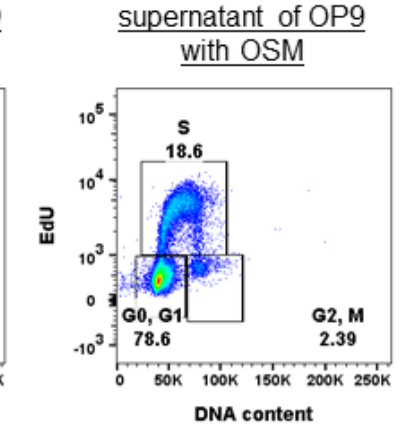

DNA content
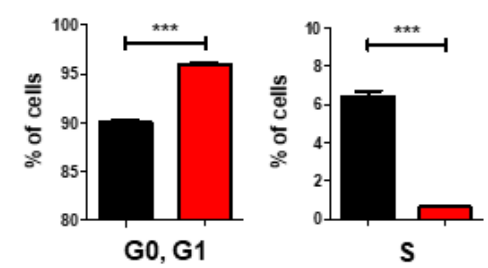

control (supernatant)

OSM (supernatant)
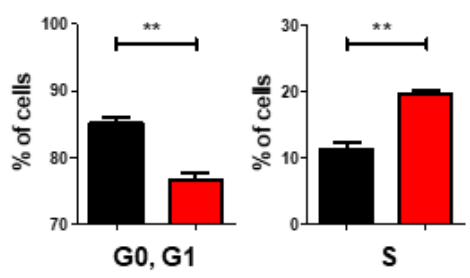

C

OP9

NIH/3T3

MCP-1

Sphase

Sphase
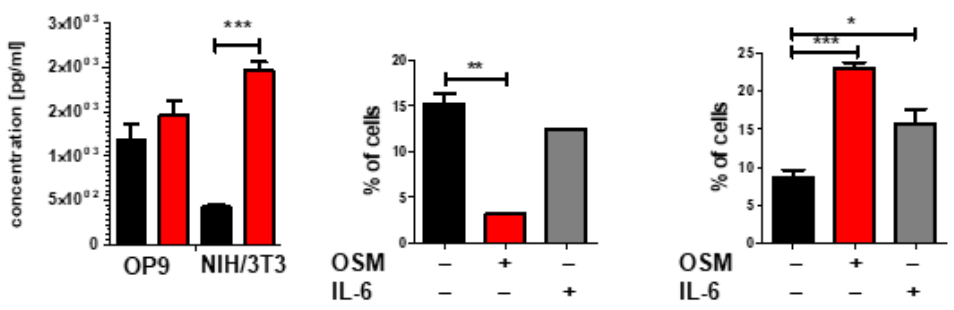

NIH/3T3

E

NIH/3T3

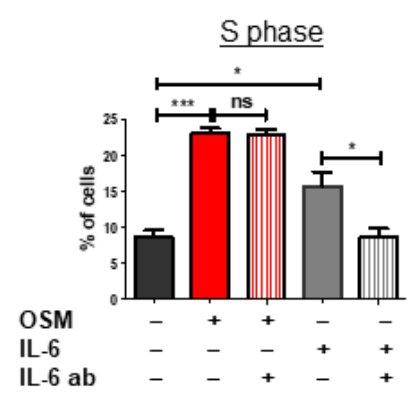

Figure 6. IL-6 has synergistic effects to OSM on the proliferation of NIH/3T3 cells. (A) Representative FACS plot (left) and quantification of cell cycle phases (right) of OP9 and NIH/3T3 cells with supernatant from the other respective cell line. Cells were treated with $10 \mathrm{ng} / \mathrm{mL}$ mOSM. Student's unpaired $t$-test. ${ }^{* *} p<0.01$, and ${ }^{* * *} p<0.001$. (B) Cytokine secretion of $\mathrm{OP9}$ and NIH/3T3 cells (+/- mOSM treatment) was measured using a bead-based array detecting 13 cytokines. Student's unpaired $t$-test ${ }^{* * *} p<0.001$. (C) Quantification of the S phase for OP9 and NIH/3T3 untreated or treated with $10 \mathrm{ng} / \mathrm{mL}$ mOSM or mIL-6. Student's unpaired $t$-test. ${ }^{*} p<0.05,{ }^{* *} p<0.01$, and ${ }^{* * *} p<0.001$. (D) Phospho-specific STAT3 flow cytometry analysis of $\mathrm{OP} 9$ and $\mathrm{NIH} / 3 \mathrm{~T} 3$ cells $+/-10 \mathrm{ng} / \mathrm{mL}$ IL-6. ${ }^{* *} p<0.01 . \mathrm{ns}=$ not significant. (E) Quantification of $\mathrm{S}$ phase for NIH/3T3 cells treated with $10 \mathrm{ng} / \mathrm{mL}$ mOSM + / - IL-6-ab or $10 \mathrm{ng} / \mathrm{mL}$ mIL-6 + / - IL-6 ab. One-way ANOVA and Bonferroni post-test. ${ }^{*} p<0.05$ and ${ }^{* * *} p<0.001$. ns $=$ not significant. 
We next studied the proliferative effect of mIL-6 on both cell lines and found that mIL-6 promoted the proliferation of NIH/3T3 cells (1.8-fold), albeit to a lesser extent than mOSM (2.7-fold). The proliferation of OP9 cells was not affected by mIL-6 (Figure 6C). Interestingly, phosphorylation-specific flow cytometry revealed STAT3 activation in NIH/3T3 but not in OP9 cells upon mIL-6 treatment (Figure 6D). To investigate the IL-6-mediated effects on $\mathrm{NIH} / 3 \mathrm{~T} 3$ cells further, we treated them with mOSM or mIL-6 in the presence or absence of neutralizing IL-6 antibodies. While treatment of NIH/3T3 cells with IL-6 neutralizing antibodies reversed the mIL-6-induced proliferation, it did not affect the OSM-induced proliferation (Figure 6E). These results suggest that the IL-6 secretion in response to mOSM is not sufficient by itself to affect the proliferation of NIH/3T3 cells and that mIL-6 and mOSM have synergistic effects on the proliferation of this cell line.

\section{Discussion}

In the present study, we investigated the OSMR dependent regulation of proliferation in OP9 and NIH/3T3 cells by mOSM. In line with previous reports [55,61], we uncovered $\mathrm{mOSM}$ as a negative regulator of proliferation of BM stromal cells and as a stimulator of proliferation in NIH/3T3 fibroblasts. OSMR and LIFR were differentially expressed between OP9 and NIH/3T3 cells. In addition, the expression of both receptors was altered upon mOSM treatment. Further investigations identified the OSMR as the key receptor in mOSM-mediated effects on proliferation.

The contribution of OSM in tumorigenesis has been controversial: Depending on the tumor entity, OSM was shown to promote tumor progression and epithelial-mesenchymal transition [44-47,62] or prevent tumor cell growth [1,40-43,49]. Our study investigated these opposing effects on proliferation as a part aspect of tumorigenesis in two defined in vitro models. When we analyzed the receptor composition of both cell lines, we detected higher overall protein levels of OSMR and especially LIFR in OP9 cells compared to $\mathrm{NIH} / 3 \mathrm{~T} 3$ cells. In addition, mOSM induced an initial downregulation of OSMR and LIFR in OP9 cells and of the OSMR in NIH/3T3 cells. We assume receptor downregulation is a consequence of receptor internalization after ligand binding followed by a compensatory enhancement of receptor expression. In subsequent knockdown experiments, we found that mOSM affects cell proliferation of both cell lines primarily by signaling through the OSMR, thus confirming previous data identifying mOSM as an activator and high-affinity binding partner of OSMR [28,29]. Studies of the huOSM system support the idea of an OSMR dependent regulation of proliferation by OSM [48].

Our study described an inferior role for the LIFR in the regulation of cellular proliferation by mOSM. Lifr overexpression was associated with attenuated effects on proliferation by mOSM in both cell lines, indicating that Lifr overexpression might act to decrease levels of free mOSM for binding to the OSMR leading to reduced effects on proliferation. In support of this hypothesis, general receptor-ligand studies showed that increased receptor surface density was associated with increased ligand occupancy [63]. Furthermore, Lifr knockdown attenuated the OSM-mediated response on proliferation in NIH/3T3 but not in OP9 cells. We assume that Lifr knockdown might have been more efficient in NIH/3T3 cells due to per se lower LIFR expression. Consequently, Lifr knockdown impaired the mOSM effect on proliferation in NIH/3T3 cells. In contrast, OP9 cells showed higher LIFR expression compared to NIH/3T3, therefore Lifr knockdown possibly did not sufficiently impair LIFR expression to detect altered mOSM effects on proliferation. Whereas our study revealed only marginal effects of mOSM-LIFR interaction on proliferation, recent studies identified the LIFR to be important in mOSM-regulated bone metabolism [30,31]. Therefore, mOSM-LIFR signaling might be dependent on the specific cellular context, similar to mOSM-OSMR signaling [28] and might exert more effects on metabolism than proliferation.

As previous research showed that huOSM affects the proliferation of chondrosarcoma and lung adenocarcinoma cells in a JAK-dependent manner [41,56], we aimed to define the exact roles of these signaling molecules in the mOSM-dependent regulation of proliferation. 
We used the JAK1 and JAK2 inhibitor ruxolitinib, which is approved for the treatment of myelofibrosis [64], polycythemia vera [65] and acute graft-versus-host disease [66], where it primarily exerts cytoreductive and antiproliferative effects. Interestingly, we found that ruxolitinib completely abolished the mOSM-mediated antiproliferative effect in OP9 cells. In line with this finding, another study identified ruxolitinib as an agent promoting hair cell growth [67]. These results indicate that ruxolitinib may exert proliferative capacities in certain cellular contexts, which should be taken into account in clinical studies with systemic use of this inhibitor.

In NIH/3T3 cells, ruxolitinib reduced OSM-induced proliferation only partly, indicating the involvement of additional mechanisms. These might include an altered abundance of signaling proteins, as we detected increased levels of total TYK2 and ERK1/2 in NIH/3T3 cells, whereas OP9 cells contained higher levels of total JAK2 und STAT5 proteins.

Downstream of JAK activation, we found phosphorylation of STAT1, 3, and 5 in both cell lines in response to mOSM treatment. Interestingly, transcriptome analysis revealed upregulation of Stat1 mRNA levels in OP9 and increased expression of Stat3 and Stat5 in NIH/3T3 cells. Active STAT3 and STAT5 signaling are known to increase proliferation in different cellular contexts [68-71], while STAT1 mainly acts as an antiproliferative factor [72-74]. Induction of proliferation in response to huOSM was also demonstrated to be related to STAT3 activation [47], whereas growth-inhibitory effects of huOSM have been found to be mediated by JAK3 and STAT1 activation [41]. Another study demonstrated that both induction and inhibition of proliferation elicited by huOSM were STAT3-dependent [48]. Based on these observations, we propose that responses to mOSM might depend on specific balances and ratios of STAT proteins and their interaction with co-activators. Indeed, previous research revealed evidence for cross-regulation between different STAT proteins $[75,76]$.

In our study, ERK expression was found to be lower in OP9 compared to NIH/3T3 cells. Interestingly, mOSM induced downregulation of ERK expression in NIH/3T3 whereas OP9 cells retained constant ERK levels. This supports previous research showing OSM-mediated downregulation of ERK expression that correlated with increased proliferation [77].

Transcriptome analysis of OP9 and NIH/3T3 cells highlighted enrichment of specific gene sets corresponding to the antiproliferative and proliferative effects of mOSM. This result was corroborated by differential RB activation in OP9 versus NIH/3T3 cells. Furthermore, another study showed downregulation of the cyclin D1/CDK4 complex and reduced pRB levels upon OSM stimulation inducing growth arrest in mouse skeletal muscle cells [78].

Future studies should further investigate the differences in signaling proteins using specific inhibitors and knockdown experiments. Moreover, OSM was shown to activate c-Jun N-terminal kinase (JNK), p38 mitogen-activated protein kinase [36] and protein kinase C-delta (PKCd) pathways [37-39]. Two studies demonstrated, that OSM stimulated the proliferation of prostate cancer cells [45] and ovarian cancer cells [47] by activation of the p38 mitogen-activated protein kinase pathway. We propose to analyze and compare the activation and expression of the mentioned pathways which might help to identify additional mechanisms leading to the opposing effects of mOSM on proliferation.

We detected mOSM-induced IL-6 secretion in OP9 and NIH/3T3 cells, which is consistent with previous reports showing IL-6 release in response to OSM in different contexts $[4,60]$. Interestingly, m-IL6 promoted the proliferation of NIH/3T3 cells but did not affect the proliferation of OP9 cells. STAT3 was not phosphorylated in OP9 cells upon mOSM treatment suggesting that these cells lack IL-6 receptor expression. However, neutralizing IL- 6 antibodies could not reverse the mOSM proliferative effect in $\mathrm{NIH} / 3 \mathrm{~T} 3$ cells. The measured IL-6 concentration in the supernatant of NIH/3T3 + mOSM $(0.0139 \mathrm{ng} / \mathrm{mL})$ was approximately $0.01 \%$ of the IL-6 concentration used for cell cycle analysis $(10 \mathrm{ng} / \mathrm{mL})$, suggesting that this IL-6 concentration was not sufficient to affect proliferation. Moreover, we assume that the pro-inflammatory cytokine IL-6 [4] contributes to the mOSM-generated inflammatory phenotype indicated by gene set enrichment analysis 
in both cell lines. IL-6 is a member of the "inflammatory response" gene set [79] and transcriptome analysis of OP9 and NIH/3T3 cells + mOSM revealed elevated IL-6 mRNA levels.

Of note, findings from studies on mOSM might not be transferred completely to the structural different huOSM. In contrast to $\mathrm{mOSM}$, huOSM was shown to bind to the type I and type II OSM-receptors with high affinity [26,27]. While huOSM is able to activate huOSMR, huLIFR, and mLIFR, mOSM does not activate any of the human receptors [28]. This suggests that to some extent different pathways might be activated by mOSM and huOSM.

Taken together, our study has demonstrated that both proliferative and antiproliferative effects of mOSM were mediated mainly through the OSMR. Based on our findings, mOSM seems to bind the LIFR with marginal but synergistic (compared to the OSMR) effects on proliferation. Furthermore, mOSM induces activation of the JAK-STAT, PI3K-AKT, and MAPK-ERK pathways in OP9 and NIH/3T3 cells with differences in total protein levels between the two cells lines. RB activation and gene set enrichment clusters correspond with the proliferative or antiproliferative response to mOSM.

Due to its multifaceted activities in various cancer entities, OSM is currently considered a novel therapeutic target, and a number of targeting antibodies and other compounds have been developed in preclinical research [80]. Our findings indicate that a more comprehensive understanding of how OSM regulates processes promoting tumor progression (such as aberrant proliferation, inflammation, modulation of the immune system, and metastasis) is required as a prerequisite to the initiation of clinical trials targeting this cytokine.

\section{Materials and Methods}

\subsection{Cell Culture}

$\mathrm{Ba} / \mathrm{F} 3$ cells and NIH/3T3 cells were obtained from the German Resource Centre for Biological Material (DSMZ). Phoenix E helper-virus free ecotropic packaging cells were a kind gift from G. Nolan, Stanford, USA. OP9 and M2-10B4 cells were a kind gift from Christine Dierks, University Hospital Freiburg, Germany. EL08-1D2 cells were kindly provided by R. A. Oostendorp, Munich, Germany. Primary murine stromal cells were isolated from C57BL/ 6 mice. Primary human stromal cells from healthy donors have been obtained from the stem cell transplant department of the University of Freiburg, Germany.

$\mathrm{Ba} / \mathrm{F} 3$ cells were maintained in RPMI 1640 medium (Thermo Fisher, Waltham, MA, USA) containing 10\% fetal calf serum (FCS; Sigma-Aldrich, St. Louis, MO, USA), $1 \%$ Penicillin-Streptomycin (PS; Thermo Fisher), and $2 \mathrm{ng} / \mathrm{mL}$ murine interleukin-3 (IL-3; Peprotech, Cranbury, NJ, USA). Phoenix E and NIH/3T3 cells were maintained in DMEM (Thermo Fisher) supplemented with $10 \%$ FCS. NIH/3T3 cells were cultivated in presence of 1\% PS. OP9 cells and M2-10B4 cells were maintained in alpha-MEM (Thermo Fisher) supplemented with 10\% FCS and 1\% PS. EL08-1D2 cells were maintained in alpha-MEM supplemented with 7.5\% FCS, 2.5\% horse serum (Thermo Fisher), $1 \%$ PS und $200 \mu \mathrm{L}$ ßMercaptoethanol (50 mM; Thermo Fisher). All cells were cultured at $37^{\circ} \mathrm{C}$ with $95 \% \mathrm{O}_{2}$, $5 \% \mathrm{CO}_{2}$.

\subsection{Cell Culture Supplements}

Murine recombinant OSM was purchased from Cell Signaling (Danvers, MA, USA). Human recombinant OSM and murine recombinant IL-6 were purchased from Peprotech. Cytokines were used at a final concentration of $10 \mathrm{ng} / \mathrm{mL}$. Ruxolitinib was purchased from ChemieTek, Indianapolis, IN, USA, the neutralizing anti-IL-6 antibody (MM600C) from Thermo Fisher.

\subsection{Retrovirus Production and Transduction}

Phoenix E cells were transiently transfected using Turbofect (Thermo Fisher) and retroviral stocks were collected twice at 12-h intervals beginning $24 \mathrm{~h}$ after transfection. 
OP9 and NIH/3T3 cells were stably transduced with retroviral supernatant supplemented with $4 \mu \mathrm{g} / \mathrm{mL}$ polybrene (Sigma Aldrich, Saint Louis, MO, USA) for 3 times every $12 \mathrm{~h}$.

\subsection{Proliferation Assays}

Proliferation was assessed using Click-iT ${ }^{\circledR}$ EdU Alexa Fluor ${ }^{\circledR} 647$ Flow Cytometry Assay Kit (Thermo Fisher) according to the manufacturer's instruction. DNA content was quantified using FxCycle ${ }^{\mathrm{TM}}$ Violet Stain (Thermo Fisher) according to the manufacturer's instruction. EdU was used at a concentration of $20 \mu \mathrm{M}$.

Cells were treated for $24 \mathrm{~h}$ with mOSM or huOSM, respectively. EdU was added during the last hour of treatment or the last $12 \mathrm{~h}$ of treatment for primary stromal cells. For experiments comparing $\mathrm{OP} 9$ and $\mathrm{NIH} / 3 \mathrm{~T} 3$ cells, cells were serum-starved with $1 \% \mathrm{FCS}$ for six hours before and during treatment. Ruxolitinib was added at the same time as mOSM for proliferation assays.

\subsection{DNA Constructs and Knockdown}

Murine wildtype Lifr cDNA (MR221059) was obtained from OriGene (Rockville, MD, USA). The retroviral vector was constructed by cloning the Lifr cDNA into the MigRI retroviral vector coexpressing the enhanced green fluorescent protein (EGFP; a kind gift from W. Pear, Philadelphia, PA, USA) [81]. Empty MigRI was used as a control for Lifr overexpression. RIEP (rtTA-IRES-EcoReceptor-PGK-PuroR), TREBAV (TRE-dsRed-miRE-PGK-BSDr2A-Venus), and pSuper plasmids were kindly provided by C. Miething, Freiburg, Germany. For doxycycline-inducible knockdown of Lifr or Osmr respectively, OP9 and NIH/3T3 cells were stably transduced first with RIEP and subsequently with TREBAV vectors containing the appropriate shRNA. All cell lines including control cell lines were cultured in presence of $1 \mu \mathrm{g} / \mathrm{mL}$ doxycycline. Doxycycline was added at least $48 \mathrm{~h}$ before starting experiments. The following shRNA sequences were used for the knockdown experiments: Lifr $5^{\prime}$ TGCTGTTGACAGTGAGCGCTACCATGTTGCTGTAGACAAATAGTGAAGCCACAGATGTATTTGTCTACAGCAACATGGTAATGCCTACTGCCTCGGA3` (here named: Lifr 1), Osmr $5^{\prime}$ TGCTGTTGACAGTGAGCGCAAGCATCTTCTTGTAAACTTATAGTGAAGCCACAGATGTATAAGTTTACAAGAAGATGCTTTTGCCTACTGCCTCGGA3' (here named: Osmr 5) and Renilla (control) 5' CGCGACTCCTATAATTTCTAATTAGTGAAGCCACAGATGTAATTAGAAATTATAGGAGTCGCT3 ${ }^{\prime}$. Further shRNA sequences are described in Table S7. All constructs were verified by sequencing.

\subsection{Flow Cytometric Analysis and Cell Sorting}

Flow cytometry was performed using an LSRFortessa ${ }^{\mathrm{TM}}$ (Becton Dickinson, Franklin Lakes, NJ, USA) cytometer and FlowJo 10.4 was used to analyze the data.

Antibodies used were: LIFRalpha (FAB5990P; R\&D Systems, Minneapolis, MN, USA) and pSTAT3 (557815, Becton Dickinson). Cells were sorted on an Aria III ${ }^{\mathrm{TM}}$ (BectonDickinson) as described before [82,83]. Antibodies used for cell sorting were CD45 (250451-82; Thermo Fisher), Ter-119 (116222; Biolegend, San Diego, CA, USA), Gr-1 (108416, Biolegend), CD3 (25-0031-82, Thermo Fisher) and CD11b (25-0112-82, Thermo Fisher). CD31 (102422, Biolegend) Sca-1 (108126, Biolegend), CD166 (12166182, eBioscience, San Diego, CA, USA) and CD140 (135906, Biolegend).

\subsection{Immunoblotting}

Immunoblot analysis was performed as previously described [84]. Cells were lysed in lysis buffer containing $10 \mathrm{mM}$ Tris (tris(hydroxymethyl) aminomethane)- $\mathrm{HCl}(\mathrm{pH}$ 7.5), $130 \mathrm{mM} \mathrm{NaCl}, 5 \mathrm{mM}$ EDTA (ethylenediaminetetraacetic acid), $1 \%$ Triton $^{\mathrm{TM}} \mathrm{X}-100$, $20 \mathrm{mM}$ sodium phosphate ( $\mathrm{pH} 7.5), 10 \mathrm{mM}$ sodium pyrophosphate ( $\mathrm{pH} 7.0), 50 \mathrm{mM} \mathrm{NaF}$, $1 \mathrm{mM}$ sodium orthovanadate, $1 \mathrm{mM}$ glycerolphosphate, and protease inhibitors (Roche Diagnostics, Basel, Switzerland). Blotting was performed on polyvinylidene fluoride (PVDF) membranes (Immobilon-P; Merck Millipore, Billerica, MA, USA). Antibodies against pAKT (cs9271), AKT (cs9272), pERK1/2 (cs9101), ERK1/2 (cs4695), pJAK2 (cs4406), 
JAK2 (cs3230), pJAK3 (cs5031), JAK3 (cs8863), pRB (cs8516), pSTAT1 (cs7649), pSTAT3 (cs9131), STAT3 (cs9132), pSTAT5 (cs9314), STAT5 (cs94205) and pTYK2 (cs9321) were purchased from Cell Signaling. TYK2 (sc5271), LIFR (sc515337), OSMR (sc376511), RB (sc50) and Vinculin (sc73614) were from Santa Cruz, Dallas, TX, USA. pJAK1 (44-422G) was from Thermo Fisher. STAT1 (21120) was from Becton Dickinson. B-actin (A5316) was from Sigma. Vinculin and $B$-actin were used as loading controls. Secondary antibodies used were mouse IgG HRP-linked (cs7076) and rabbit IgG HRP-linked (cs7074) from Cell Signaling. Blots were developed using SuperSignal ${ }^{\mathrm{TM}}$ chemoluminescent substrates (Thermo Fisher). Quantification of Western Blots was done using LabImage 1D Sofware (Intas Science Imaging, Göttingen, Germany).

\subsection{Cytokine Array}

Cytokine secretion was measured using LEGENDplex ${ }^{\mathrm{TM}}$ Mouse Inflammation Panel (Biolegend) according to the manufacturer's instruction. The cytokine array was performed using an LSRFortessa ${ }^{\mathrm{TM}}$ (Becton Dickinson, Franklin Lakes, NJ, USA) cytometer.

\subsection{RNA Isolation and Microarray}

RNA was isolated with the RNeasy Mini Kit (Qiagen) and transcribed into cDNA with the First Strand cDNA Synthesis Kit (Thermo Fisher). RNA quality was assayed using an Agilent 4200 TapeStation (Agilent Technologies, Santa Clara, CA, USA). Mouse Clariom S Assay (Thermo Fisher) was used to analyze mRNA expression according to the manufacturer's instructions. The $p$-values were calculated by Transcriptome Analysis Console (Affymetrix) software. Data were analyzed using Metascape analysis (Metascape A Gene Annotation and Analysis Resource. Available online: http://metascape.org/, accessed on 21 October 2021) [85] with gene symbols from genes with $>2$-fold upregulation or downregulation and $p<0.05$ in control cells compared to mOSM treated cells. Microarray data have been deposited to the Gene Expression Omnibus (GEO) and will be accessible through GEO Series accession number GSE185646.

\subsection{Statistical Analysis}

Statistical analysis was performed using GraphPad Prism software. $p$-Values were determined by Student's $t$-test and one-way ANOVA with Bonferroni post-test for comparison of more than two groups. Data are represented as means \pm SEM.

Supplementary Materials: The following are available online at https:/ /www.mdpi.com/article/10 .3390/ijms222111649/s1.

Author Contributions: Conceptualization, J.D.; validation, L.J., T.A.M. and M.R.; formal analysis, L.J., T.A.M. and M.R.; resources, J.D.; data curation, L.J., H.K., T.A.M., M.R., D.P., P.V., J.M., C.M., M.W. and R.A.J.O.; writing—original draft preparation, L.J., M.R., T.A.M. and J.D.; writing—review and editing, L.J., M.R., T.A.M., R.A.J.O. and J.D.; visualization, J.D., L.J., T.A.M. and M.R.; supervision, J.D.; project administration, T.A.M. and M.R.; funding acquisition, J.D., T.A.M. and M.R. All authors have read and agreed to the published version of the manuscript.

Funding: T.A.M., M.R. and J.D. were funded by a collaborative research project from the Deutsche Forschungsgemeinschaft (FOR2033 B1 and B3). T.A.M was supported by a research grant from the Deutsche José Carreras Leukämie-Stiftung (DJCLS 02 FN/2017). J.D. is supported by the German Research Foundation (DFG) (SFB1479).

Institutional Review Board Statement: The study was conducted according to the guidelines of the Declaration of Helsinki and approved by the Institutional Ethics Committee (ethical approval nr. 18/128, date of approval: 14 November 2018). All human healthy controls gave written consent before stem cell donation.

Informed Consent Statement: Informed consent was obtained from all subjects involved in the study. 
Data Availability Statement: Publicly available datasets were analyzed in this study. This data can be found here Gene Expression Omnibus. Available online: https:/ / www.ncbi.nlm.nih.gov/geo/ query /acc.cgi?acc=GSE185646, Accession number: GSE185646 (accessed on 21 October 2021).

Acknowledgments: The authors thank D. Herchenbach and M. Follo for fluorescence-activated cell sorting.

Conflicts of Interest: The authors declare no conflict of interest.

\section{References}

1. Zarling, J.M.; Shoyab, M.; Marquardt, H.; Hanson, M.B.; Lioubin, M.N.; Todaro, G. Oncostatin M: A growth regulator produced by differentiated histiocytic lymphoma cells. Proc. Natl. Acad. Sci. USA 1986, 83, 9739-9743. [CrossRef] [PubMed]

2. Miyajima, A.; Kinoshita, T.; Tanaka, M.; Kamiya, A.; Mukouyama, Y.; Hara, T. Role of Oncostatin M in hematopoiesis and liver development. Cytokine Growth Factor Rev. 2000, 11, 177-183. [CrossRef]

3. Malik, N.; Haugen, H.S.; Modrell, B.; Shoyab, M.; Clegg, C.H. Developmental abnormalities in mice transgenic for bovine oncostatin M. Mol. Cell Biol. 1995, 15, 2349-2358. [CrossRef] [PubMed]

4. West, N.R.; Hegazy, A.N.; Owens, B.M.J.; Bullers, S.J.; Linggi, B.; Buonocore, S.; Coccia, M.; Görtz, D.; This, S.; Stockenhuber, K.; et al. Oncostatin M drives intestinal inflammation in mice and its abundance predicts response to tumor necrosis factorneutralizing therapy in patients with inflammatory bowel disease. Nat. Med. 2017, 23, 579-589. [CrossRef]

5. Minehata, K.; Takeuchi, M.; Hirabayashi, Y.; Inoue, T.; Donovan, P.J.; Tanaka, M.; Miyajima, A. Oncostatin m maintains the hematopoietic microenvironment and retains hematopoietic progenitors in the bone marrow. Int. J. Hematol. 2006, 84, 319-327. [CrossRef]

6. Tanaka, M.; Hirabayashi, Y.; Sekiguchi, T.; Inoue, T.; Katsuki, M.; Miyajima, A. Targeted disruption of oncostatin M receptor results in altered hematopoiesis. Blood 2003, 102, 3154-3162. [CrossRef]

7. Gurluler, E.; Tumay, L.V.; Guner, O.S.; Kucukmetin, N.T.; Hizli, B.; Zorluoglu, A. Oncostatin-M as a novel biomarker in colon cancer patients and its association with clinicopathologic variables. Eur. Rev. Med. Pharmacol. Sci. 2014, 18, $2042-2047$.

8. Torres, C.; Perales, S.; Alejandre, M.J.; Iglesias, J.; Palomino, R.J.; Martin, M.; Caba, O.; Prados, J.C.; Aránega, A.; Delgado, J.R.; et al. Serum cytokine profile in patients with pancreatic cancer. Pancreas 2014, 43, 1042-1049. [CrossRef]

9. Koskela, K.; Pelliniemi, T.-T.; Remes, K.; Rajamäki, A.; Pulkki, K. Serum oncostatin M in multiple myeloma: Association with prognostic factors. Br. J. Haematol. 1997, 96, 158-160. [CrossRef]

10. Lilja, A.; Nordborg, C.; Brun, A.; Salford, L.; Aman, P. Expression of the IL-6 family cytokines in human brain tumors. Int. J. Oncol. 2001, 19, 495-499. [CrossRef]

11. Robak, T.; Wierzbowska, A.; Błasińska-Morawiec, M.; Korycka, A.; Błoński, J.Z. Serum Levels of IL-6 Type Cytokines and Soluble IL-6 Receptors in Active B-Cell Chronic Lymphocytic Leukemia and in Cladribine Induced Remission. Mediat. Inflamm. 1999, 8 , 277-286. [CrossRef]

12. Liang, H.; Block, T.M.; Wang, M.; Nefsky, B.; Long, R.; Hafner, J.; Mehta, A.S.; Marrero, J.; Gish, R.; Norton, P.A. Interleukin-6 and oncostatin $\mathrm{M}$ are elevated in liver disease in conjunction with candidate hepatocellular carcinoma biomarker GP73. Cancer Biomark. 2012, 11, 161-171. [CrossRef] [PubMed]

13. Scotto, L.; Narayan, G.; Nandula, S.V.; Subramaniyam, S.; Kaufmann, A.M.; Wright, J.D.; Pothuri, B.; Mansukhani, M.; Schneider, A.; Arias-Pulido, H.; et al. Integrative genomics analysis of chromosome 5p gain in cervical cancer reveals target over-expressed genes, including Drosha. Mol. Cancer 2008, 7, 58. [CrossRef] [PubMed]

14. Torossian, F.; Guerton, B.; Anginot, A.; Alexander, K.A.; Desterke, C.; Soave, S.; Tseng, H.-W.; Arouche, N.; Boutin, L.; Kulina, I.; et al. Macrophage-derived oncostatin M contributes to human and mouse neurogenic heterotopic ossifications. JCI Insight 2017, 2, e96034. [CrossRef] [PubMed]

15. Guihard, P.; Danger, Y.; Brounais, B.; David, E.; Brion, R.; Delecrin, J.; Richards, C.D.; Chevalier, S.; Rédini, F.; Heymann, D.; et al. Induction of osteogenesis in mesenchymal stem cells by activated monocytes/macrophages depends on oncostatin $\mathrm{M}$ signaling. Stem Cells 2012, 30, 762-772. [CrossRef]

16. Broxmeyer, H.E.; Bruns, H.A.; Zhang, S.; Cooper, S.; Hangoc, G.; McKenzie, A.N.; Dent, A.L.; Schindler, U.; Naeger, L.K.; Hoey, T.; et al. Th1 cells regulate hematopoietic progenitor cell homeostasis by production of oncostatin M. Immunity 2002, 16, 815-825. [CrossRef]

17. Brown, T.J.; Lioubin, M.N.; Marquardt, H. Purification and characterization of cytostatic lymphokines produced by activated human T lymphocytes. Synergistic antiproliferative activity of transforming growth factor beta 1, interferon-gamma, and oncostatin M for human melanoma cells. J. Immunol. 1987, 139, 2977-2983.

18. Suda, T.; Chida, K.; Todate, A.; Ide, K.; Asada, K.; Nakamura, Y.; Suzuki, K.; Kuwata, H.; Nakamura, H. Oncostatin M Production by Human Dendritic Cells In Response To Bacterial Products. Cytokine 2002, 17, 335-340. [CrossRef] [PubMed]

19. Goren, I.; Kämpfer, H.; Müller, E.; Schiefelbein, D.; Pfeilschifter, J.; Frank, S. Oncostatin M expression is functionally connected to neutrophils in the early inflammatory phase of skin repair: Implications for normal and diabetes-impaired wounds. J. Investig. Derm. 2006, 126, 628-637. [CrossRef]

20. Grenier, A.; Combaux, D.; Chastre, J.; Gougerot-Pocidalo, M.A.; Gibert, C.; Dehoux, M.; Chollet-Martin, S. Oncostatin M production by blood and alveolar neutrophils during acute lung injury. Lab. Investig. 2001, 81, 133-141. [CrossRef] 
21. Grenier, A.; Dehoux, M.; Boutten, A.; Arce-Vicioso, M.; Durand, G.; Gougerot-Pocidalo, M.A.; Chollet-Martin, S. Oncostatin M production and regulation by human polymorphonuclear neutrophils. Blood 1999, 93, 1413-1421. [CrossRef]

22. Queen, M.M.; Ryan, R.E.; Holzer, R.G.; Keller-Peck, C.R.; Jorcyk, C.L. Breast cancer cells stimulate neutrophils to produce oncostatin M: Potential implications for tumor progression. Cancer Res. 2005, 65, 8896-8904. [CrossRef]

23. Setiadi, H.; Yago, T.; Liu, Z.; McEver, R.P. Endothelial signaling by neutrophil-released oncostatin M enhances P-selectindependent inflammation and thrombosis. Blood Adv. 2019, 3, 168-183. [CrossRef] [PubMed]

24. Taga, T.; Hibi, M.; Hirata, Y.; Yamasaki, K.; Yasukawa, K.; Matsuda, T.; Hirano, T.; Kishimoto, T. Interleukin-6 triggers the association of its receptor with a possible signal transducer, gp130. Cell 1989, 58, 573-581. [CrossRef]

25. Hirano, T.; Matsuda, T.; Nakajima, K. Signal transduction through gp130 that is shared among the receptors for the interleukin 6 related cytokine subfamily. Stem Cells 1994, 12, 262-277. [CrossRef] [PubMed]

26. Gearing, D.P.; Comeau, M.R.; Friend, D.J.; Gimpel, S.D.; Thut, C.J.; McGourty, J.; Brasher, K.K.; King, J.A.; Gillis, S.; Mosley, B. The IL-6 signal transducer, gp130: An oncostatin M receptor and affinity converter for the LIF receptor. Science 1992, 255, 1434-1437. [CrossRef] [PubMed]

27. Mosley, B.; Imus C de Friend, D.; Boiani, N.; Thoma, B.; Park, L.S.; Cosman, D. Dual oncostatin M (OSM) receptors. Cloning and characterization of an alternative signaling subunit conferring OSM-specific receptor activation. J. Biol. Chem. 1996, 271, 32635-32643. [CrossRef]

28. Lindberg, R.A.; Juan, T.S.-C.; Welcher, A.A.; Sun, Y.; Cupples, R.; Guthrie, B.; Fletcher, F.A. Cloning and Characterization of a Specific Receptor for Mouse Oncostatin, M. Mol. Cell. Biol. 1998, 18, 3357-3367. [CrossRef]

29. Ichihara, M.; Hara, T.; Kim, H.; Murate, T.; Miyajima, A. Oncostatin M and leukemia inhibitory factor do not use the same functional receptor in mice. Blood 1997, 90, 165-173. [CrossRef] [PubMed]

30. Walker, E.C.; McGregor, N.E.; Poulton, I.J.; Solano, M.; Pompolo, S.; Fernandes, T.J.; Constable, M.J.; Nicholson, G.C.; Zhang, J.G.; Nicola, N.A.; et al. Oncostatin M promotes bone formation independently of resorption when signaling through leukemia inhibitory factor receptor in mice. J. Clin. Investig. 2010, 120, 582-592. [CrossRef]

31. Walker, E.C.; Johnson, R.W.; Hu, Y.; Brennan, H.J.; Poulton, I.J.; Zhang, J.-G.; Jenkins, B.J.; Smyth, G.K.; Nicola, N.A.; Sims, N. Murine Oncostatin M Acts via Leukemia Inhibitory Factor Receptor to Phosphorylate Signal Transducer and Activator of Transcription 3 (STAT3) but Not STAT1, an Effect That Protects Bone Mass. J. Biol. Chem. 2016, 291, 21703-21716. [CrossRef] [PubMed]

32. Lonsdale, J.; Thomas, J.; Salvatore, M.; Phillips, R.; Lo, E.; Shad, S.; Hasz, R.; Walters, G.; Garcia, F.; Young, N.; et al. The Genotype-Tissue Expression (GTEx) project. Nat. Genet. 2013, 45, 580-585. [CrossRef]

33. Auguste, P.; Guillet, C.; Fourcin, M.; Olivier, C.; Veziers, J.; Pouplard-Barthelaix, A.; Gascan, H. Signaling of type II oncostatin M receptor. J. Biol. Chem. 1997, 272, 15760-15764. [CrossRef]

34. Hermanns, H.M.; Radtke, S.; Schaper, F.; Heinrich, P.C.; Behrmann, I. Non-redundant signal transduction of interleukin-6-type cytokines. The adapter protein Shc is specifically recruited to rhe oncostatin M receptor. J. Biol. Chem. 2000, 275, 40742-40748. [CrossRef]

35. Hermanns, H.M.; Radtke, S.; Haan, C.; Schmitz-Van de Leur, H.; Tavernier, J.; Heinrich, P.C.; Behrmann, I. Contributions of leukemia inhibitory factor receptor and oncostatin $\mathrm{M}$ receptor to signal transduction in heterodimeric complexes with glycoprotein 130. J. Immunol. 1999, 163, 6651-6658.

36. Böing, I.; Stross, C.; Radtke, S.; Lippok, B.E.; Heinrich, P.C.; Hermanns, H.M. Oncostatin M-induced activation of stress-activated MAP kinases depends on tyrosine 861 in the OSM receptor and requires Jak1 but not Src kinases. Cell. Signal. 2006, 18, 50-61. [CrossRef]

37. David, C.; Smyth, C.K.; Richards, D.C. Oncostatin M-Induced IL-6 Expression in Murine Fibroblasts Requires the Activation of Protein Kinase C $\delta$. J. Immunol. 2006, 177, 8740-8747. [CrossRef]

38. Smyth, D.C.; Takenaka, S.; Yeung, C.; Richards, C.D. Oncostatin M regulates osteogenic differentiation of murine adipose-derived mesenchymal progenitor cells through a PKCdelta-dependent mechanism. Cell Tissue Res. 2015, 360, 309-319. [CrossRef] [PubMed]

39. Schnittker, D.; Kwofie, K.; Ashkar, A.; Trigatti, B.; Richards, C.D. Oncostatin M and TLR-4 ligand synergize to induce MCP-1, IL-6, and VEGF in human aortic adventitial fibroblasts and smooth muscle cells. Mediat. Inflamm. 2013, 2013, 317503. [CrossRef]

40. Li, C.; Ahlborn, T.E.; Kraemer, F.B.; Liu, J. Oncostatin M-induced growth inhibition and morphological changes of MDA-MB231 breast cancer cells are abolished by blocking the MEK/ERK signaling pathway. Breast Cancer Res. Treat. 2001, 66, 111-121. [CrossRef] [PubMed]

41. David, E.; Guihard, P.; Brounais, B.; Riet, A.; Charrier, C.; Battaglia, S.; Gouin, F.; Ponsolle, S.; Le Bot, R.; Richards, C.D.; et al. Direct anti-cancer effect of oncostatin M on chondrosarcoma. Int. J. Cancer 2011, 128, 1822-1835. [CrossRef]

42. Wang, M.-L.; Pan, C.-M.; Chiou, S.-H.; Chen, W.-H.; Chang, H.-Y.; Lee, O.K.-S.; Hsu, H.-S.; Wu, C.-W. Oncostatin m modulates the mesenchymal-epithelial transition of lung adenocarcinoma cells by a mesenchymal stem cell-mediated paracrine effect. Cancer Res. 2012, 72, 6051-6064. [CrossRef]

43. Friedrich, M.; Höss, N.; Stögbauer, F.; Senner, V.; Paulus, W.; Ringelstein, E.B.; Halfter, H. Complete inhibition of in vivo glioma growth by oncostatin M. J. Neurochem. 2001, 76, 1589-1592. [CrossRef]

44. Mori, S.; Murakami-Mori, K.; Bonavida, B. Oncostatin M (OM) promotes the growth of DU 145 human prostate cancer cells, but not PC-3 or LNCaP, through the signaling of the OM specific receptor. Anticancer Res. 1999, 19, 1011-1015. 
45. Godoy-Tundidor, S.; Cavarretta, I.T.R.; Fuchs, D.; Fiechtl, M.; Steiner, H.; Friedbichler, K.; Bartsch, G.; Hobisch, A.; Culig, Z. Interleukin- 6 and oncostatin M stimulation of proliferation of prostate cancer $22 \mathrm{Rv} 1$ cells through the signaling pathways of p38 mitogen-activated protein kinase and phosphatidylinositol 3-kinase. Prostate 2005, 64, 209-216. [CrossRef]

46. Lee, M.J.; Heo, S.C.; Shin, S.H.; Kwon, Y.W.; Do, E.K.; Suh, D.-S.; Yoon, M.-S.; Kim, J.H. Oncostatin M promotes mesenchymal stem cell-stimulated tumor growth through a paracrine mechanism involving periostin and TGFBI. Int. J. Biochem. Cell Biol. 2013, 45, 1869-1877. [CrossRef] [PubMed]

47. Li, Q.; Zhu, J.; Sun, F.; Liu, L.; Liu, X.; Yue, Y. Oncostatin M promotes proliferation of ovarian cancer cells through signal transducer and activator of transcription 3. Int. J. Mol. Med. 2011, 28, 101-108. [CrossRef] [PubMed]

48. David, E.; Tirode, F.; Baud'huin, M.; Guihard, P.; Laud, K.; Delattre, O.; Heymann, M.F.; Heymann, D.; Redini, F.; Blanchard, F. Oncostatin $\mathrm{M}$ is a growth factor for Ewing sarcoma. Am. J. Pathol. 2012, 181, 1782-1795. [CrossRef]

49. Wang, H.; Lei, L.; Hu, J.; Li, Y. Oncostatin M upregulates Livin to promote keratinocyte proliferation and survival via ERK and STAT3 signalling pathways. Exp. Physiol. 2020, 105, 1151-1158. [CrossRef]

50. Schwaller, J.; Parganas, E.; Wang, D.; Cain, D.; Aster, J.C.; Williams, I.R.; Lee, C.-K.; Gerthner, R.; Kitamura, T.; Frantsve, J.; et al. Stat5 Is Essential for the Myelo- and Lymphoproliferative Disease Induced by TEL/JAK2. Mol. Cell 2000, 6, 693-704. [CrossRef]

51. Müller, T.A.; Grundler, R.; Istvanffy, R.; Rudelius, M.; Hennighausen, L.; Illert, A.L.; Duyster, J. Lineage-specific STAT5 target gene activation in hematopoietic progenitor cells predicts the FLT3(+)-mediated leukemic phenotype. Leukemia 2016, 30, 1725-1733. [CrossRef] [PubMed]

52. Bisht, K.; McGirr, C.; Lee, S.-Y.; Tseng, H.-W.; Fleming, W.; Alexander, K.A.; Matsumoto, T.; Barbier, V.; Sims, N.A.; Müller-Newen, G.; et al. Oncostatin M regulates hematopoietic stem cell (HSC) niches in the bone marrow to restrict HSC mobilization. Leukemia 2021. [CrossRef] [PubMed]

53. Zhou, Y.; Bian, S.; Zhou, X.; Cui, Y.; Wang, W.; Wen, L.; Guo, L.; Fu, W.; Tang, F. Single-Cell Multiomics Sequencing Reveals Prevalent Genomic Alterations in Tumor Stromal Cells of Human Colorectal Cancer. Cancer Cell 2020, 38, 818-828.e5. [CrossRef] [PubMed]

54. Ren, G.; Zhao, X.; Wang, Y.; Zhang, X.; Chen, X.; Xu, C.; Yuan, Z.-R.; Roberts, A.I.; Zhang, L.; Zheng, B.; et al. CCR2-Dependent Recruitment of Macrophages by Tumor-Educated Mesenchymal Stromal Cells Promotes Tumor Development and Is Mimicked by TNF $\alpha$. Cell Stem Cell 2012, 11, 812-824. [CrossRef] [PubMed]

55. Horn, D.; Fitzpatrick, W.C.; Gompper, P.T.; Ochs, V.; Bolton-Hansen, M.; Zarling, J.; Malik, N.; Todaro, G.J.; Linsley, P.S. Regulation of cell growth by recombinant oncostatin M. Growth Factors 1990, 2, 157-165. [CrossRef]

56. Wang, E.C.E.; Dai, Z.; Ferrante, A.W.; Drake, C.G.; Christiano, A.M. A Subset of TREM2+ Dermal Macrophages Secretes Oncostatin M to Maintain Hair Follicle Stem Cell Quiescence and Inhibit Hair Growth. Cell Stem Cell 2019, 24, 654-669.e6. [CrossRef] [PubMed]

57. Tvorogov, D.; Thomas, D.; Liau, N.P.D.; Dottore, M.; Barry, E.F.; Lathi, M.; Kan, W.L.; Hercus, T.R.; Stomski, F.; Hughes, T.P.; et al. Accumulation of JAK activation loop phosphorylation is linked to type I JAK inhibitor withdrawal syndrome in myelofibrosis. Sci. Adv. 2018, 4, eaat3834. [CrossRef]

58. Su, C.-M.; Lee, W.-L.; Hsu, C.-J.; Lu, T.-T.; Wang, L.-H.; Xu, G.-H.; Tang, C.-H. Adiponectin Induces Oncostatin M Expression in Osteoblasts through the PI3K/Akt Signaling Pathway. Int. J. Mol. Sci. 2015, 17, 29. [CrossRef]

59. West, N.R.; Murray, J.I.; Watson, P.H. Oncostatin-M promotes phenotypic changes associated with mesenchymal and stem cell-like differentiation in breast cancer. Oncogene 2014, 33, 1485-1494. [CrossRef]

60. Brown, T.J.; Rowe, J.M.; Liu, J.W.; Shoyab, M. Regulation of IL-6 expression by oncostatin M. J. Immunol. 1991, 147, $2175-2180$.

61. Yanai, N.; Obinata, M. Oncostatin $m$ regulates mesenchymal cell differentiation and enhances hematopoietic supportive activity of bone marrow stromal cell lines. In vitro cellular \& developmental biology. Animal 2001, 37, 698-704. [CrossRef]

62. Guo, L.; Chen, C.; Shi, M.; Wang, F.; Chen, X.; Diao, D.; Hu, M.; Yu, M.; Qian, L.; Guo, N. Stat3-coordinated Lin-28-let-7-HMGA2 and miR-200-ZEB1 circuits initiate and maintain oncostatin M-driven epithelial-mesenchymal transition. Oncogene 2013, 32, 5272-5282. [CrossRef] [PubMed]

63. Gavin, E.; Jarvis, A.J. Thompson Evidence for an effect of receptor density on ligand occupancy and agonist EC 50. Sci. Rep. 2013, 9, 1-12. [CrossRef]

64. Verstovsek, S.; Mesa, R.A.; Gotlib, J.; Levy, R.S.; Gupta, V.; DiPersio, J.F.; Catalano, J.V.; Deininger, M.; Miller, C.; Silver, R.T.; et al. A double-blind, placebo-controlled trial of ruxolitinib for myelofibrosis. N. Engl. J. Med. 2012, 366, 799-807. [CrossRef] [PubMed]

65. Vannucchi, A.M.; Kiladjian, J.J.; Griesshammer, M.; Masszi, T.; Durrant, S.; Passamonti, F.; Harrison, C.N.; Pane, F.; Zachee, P.; Mesa, R.; et al. Ruxolitinib versus standard therapy for the treatment of polycythemia vera. N. Engl. J. Med. 2015, 372, 426-435. [CrossRef] [PubMed]

66. Zeiser, R.; Bubnoff, N.; von Butler, J.; Mohty, M.; Niederwieser, D.; Or, R.; Szer, J.; Wagner, E.M.; Zuckerman, T.; Mahuzier, B.; et al. Ruxolitinib for Glucocorticoid-Refractory Acute Graft-versus-Host Disease. N. Engl. J. Med. 2020, 382, 1800-1810. [CrossRef]

67. Harel, S.; Higgins, C.A.; Cerise, J.E.; Dai, Z.; Chen, J.C.; Clynes, R.; Christiano, A.M. Pharmacologic inhibition of JAK-STAT signaling promotes hair growth. Sci. Adv. 2015, 1, e1500973. [CrossRef] [PubMed]

68. Araujo ED de Keserú, G.M.; Gunning, P.T.; Moriggl, R. Targeting STAT3 and STAT5 in Cancer. Cancers 2020, 12, 2002. [CrossRef]

69. Walz, C.; Ahmed, W.; Lazarides, K.; Betancur, M.; Patel, N.; Hennighausen, L.; Zaleskas, V.M.; van Etten, R.A. Essential role for Stat5a/b in myeloproliferative neoplasms induced by BCR-ABL1 and JAK2(V617F) in mice. Blood 2012, 119, 3550-3560. [CrossRef] 
70. Swoboda, A.; Soukup, R.; Eckel, O.; Kinslechner, K.; Wingelhofer, B.; Schörghofer, D.; Sternberg, C.; Pham, H.T.T.; Vallianou, M.; Horvath, J.; et al. STAT3 promotes melanoma metastasis by CEBP-induced repression of the MITF pathway. Oncogene 2021, 40, 1091-1105. [CrossRef]

71. Liu, X.; Robinson, G.W.; Wagner, K.U.; Garrett, L.; Wynshaw-Boris, A.; Hennighausen, L. Stat5a is mandatory for adult mammary gland development and lactogenesis. Genes Dev. 1997, 11, 179-186. [CrossRef] [PubMed]

72. Chin, Y.E.; Kitagawa, M.; Su, W.C.; You, Z.H.; Iwamoto, Y.; Fu, X.Y. Cell growth arrest and induction of cyclin-dependent kinase inhibitor p21 WAF1/CIP1 mediated by STAT1. Science 1996, 272, 719-722. [CrossRef] [PubMed]

73. Bromberg, J.F.; Horvath, C.M.; Wen, Z.; Schreiber, R.D.; Darnell, J.E. Transcriptionally active Stat1 is required for the antiproliferative effects of both interferon alpha and interferon gamma. Proc. Natl. Acad. Sci. USA 1996, 93, 7673-7678. [CrossRef]

74. Dimberg, A.; Karlberg, I.; Nilsson, K.; Oberg, F. Ser727/Tyr701-phosphorylated Stat1 is required for the regulation of c-Myc, cyclins, and p27Kip1 associated with ATRA-induced G0/G1 arrest of U-937 cells. Blood 2003, 102, 254-261. [CrossRef]

75. Nivarthi, H.; Gordziel, C.; Themanns, M.; Kramer, N.; Eberl, M.; Rabe, B.; Schlederer, M.; Rose-John, S.; Knösel, T.; Kenner, L.; et al. The ratio of STAT1 to STAT3 expression is a determinant of colorectal cancer growth. Oncotarget 2016, 7, 51096-51106. [CrossRef]

76. Lee, C.-K.; Raz, R.; Gimeno, R.; Gertner, R.; Wistinghausen, B.; Takeshita, K.; DePinho, R.A.; Levy, D.E. STAT3 Is a Negative Regulator of Granulopoiesis but Is Not Required for G-CSF-Dependent Differentiation. Immunity 2002, 17, 63-72. [CrossRef]

77. Oostendorp, R.A.J.; Gilfillan, S.; Parmar, A.; Schiemann, M.; Marz, S.; Niemeyer, M.; Schill, S.; Hammerschmid, E.; Jacobs, V.R.; Peschel, C.; et al. Oncostatin M-mediated regulation of KIT-ligand-induced extracellular signal-regulated kinase signaling maintains hematopoietic repopulating activity of Lin-CD34+CD133+ cord blood cells. Stem Cells 2008, 26, 2164-2172. [CrossRef]

78. Kim, H.; Jo, C.; Jang, B.G.; Oh, U.; Jo, S.A. Oncostatin M induces growth arrest of skeletal muscle cells in G1 phase by regulating cyclin D1 protein level. Cell. Signal. 2008, 20, 120-129. [CrossRef]

79. Bult, C.J.; Blake, J.A.; Smith, C.L.; Kadin, J.A.; Richardson, J.E. Mouse Genome Database (MGD) 2019. Nucleic Acids Res. 2019, 47, D801-D806. [CrossRef]

80. Masjedi, A.; Hajizadeh, F.; Beigi Dargani, F.; Beyzai, B.; Aksoun, M.; Hojjat-Farsangi, M.; Zekiy, A.; Jadidi-Niaragh, F. Oncostatin M: A mysterious cytokine in cancers. Int. Immunopharmacol. 2021, 90, 107158. [CrossRef] [PubMed]

81. Pear, W.S.; Miller, J.P.; Xu, L.; Pui, J.C.; Soffer, B.; Quackenbush, R.C.; Pendergast, A.M.; Bronson, R.; Aster, J.C.; Scott, M.L.; et al. Efficient and rapid induction of a chronic myelogenous leukemia-like myeloproliferative disease in mice receiving P210 bcr/abl-transduced bone marrow. Blood 1998, 92, 3780-3792. [CrossRef]

82. Klein, C.; Zwick, A.; Kissel, S.; Forster, C.U.; Pfeifer, D.; Follo, M.; Illert, A.L.; Decker, S.; Benkler, T.; Pahl, H.; et al. Ptch2 loss drives myeloproliferation and myeloproliferative neoplasm progression. J. Exp. Med. 2016, 213, 273-290. [CrossRef] [PubMed]

83. Renström, J.; Kröger, M.; Peschel, C.; Oostendorp, R.A.J. How the niche regulates hematopoietic stem cells. Chem. Biol. Interact. 2010, 184, 7-15. [CrossRef] [PubMed]

84. Grundler, R.; Thiede, C.; Miething, C.; Steudel, C.; Peschel, C.; Duyster, J. Sensitivity toward tyrosine kinase inhibitors varies between different activating mutations of the FLT3 receptor. Blood 2003, 102, 646-651. [CrossRef] [PubMed]

85. Zhou, Y.; Zhou, B.; Pache, L.; Chang, M.; Khodabakhshi, A.H.; Tanaseichuk, O.; Benner, C.; Chanda, S.K. Metascape provides a biologist-oriented resource for the analysis of systems-level datasets. Nat. Commun. 2019, 10, 1523. [CrossRef] 